This is an Accepted Manuscript of an article published in Global Crime on 7 February 2014, available online: http://www.tandfonline.com/10.1080/17440572.2014.883499

Counterfeiting, illegal firearms, gambling and waste management: an exploratory estimation of four criminal markets

Francesco Calderoni, Serena Favarin, Lorella Garofalo, Federica Sarno

Università Cattolica del Sacro Cuore and Transcrime, Milan, Italy

francesco.calderoni@unicatt.it; serena.favarin@unicatt.it; lorella.garofalo@unicatt.it; federica.sarno@unicatt.it 


\title{
Counterfeiting, illegal firearms, gambling and waste management: an exploratory estimation of four criminal markets
}

\author{
This article focuses on four different criminal markets: namely, those of \\ counterfeiting, illegal firearms trafficking, gambling and waste management. \\ Despite recurrent allegations that these markets have a high mafia presence, \\ there is a lack of reliable estimates of their sizes and the revenues that they \\ generate. Figures in reports and media vary significantly, and the methods used to \\ obtain them are often obscure. This study develops four different estimation \\ methodologies with which to estimate the four criminal markets in Italy at the \\ national and regional level. Considering that these are the first attempts to \\ estimate these markets, the aim of the article is to stimulate debate on how to \\ improve measurement of the crime proceeds from these criminal markets.
}

Keywords: proceeds of crime; criminal markets; estimating illegal revenues; Italian mafias.

\section{Introduction}

This article describes exploratory methodologies with which to estimate the size and proceeds of four illegal markets: firearms trafficking, counterfeiting, gambling and waste management. Although these activities are very different from each other, there is a substantial lack of reliable estimates of their size in Italy and, frequently, abroad. The few estimates available often lack details on the main assumptions made and the methodologies used. The results are frequently impossible to verify and unreliable. This is particularly surprising because these illegal markets are frequently associated in the media and public opinion with criminal organizations and mafias. The lack of estimates hinders verification of the economic importance of such markets, as well as the claims made by the media and other sources. 
Given the lack of reliable methods and transparently calculated estimates for the four illegal markets, this article produces exploratory estimations of the criminal revenues deriving from them in Italy at both the national and regional level. ${ }^{1}$ The purpose is not only to elaborate the first estimates in Italy relative to the mentioned criminal activities, but also, and more importantly, to stimulate a debate on the difficulties and possibilities of measuring criminal markets. In fact, the article proposes four different approaches suited to the specific features of each market and to the data available. The assumptions, data and methods are described in detail so that both replication and improvement are possible.

In the next section, four sub-sections review current knowledge and estimates on the markets selected, with especial focus on the Italian situation. Section 3 describes the methodologies used to estimate the illegal revenues from each market and discusses their limitations. The fourth section presents and discusses the results. The last section concludes.

\section{Background on the four criminal market}

\subsection{The illegal firearms market}

The most commonly used definition of firearms trafficking is set out in Article 3 of the United Nations Protocol against the Illicit Manufacturing of and Trafficking in Firearms, Their Parts and Components and Ammunition, where it is defined as "the import, export, acquisition, sale, delivery, movement or transfer of firearms, their parts and components and ammunition from or across the territory of one State Party to that of another State Party if any one of the States Parties concerned does not authorize it in accordance with the terms of this Protocol or if the firearms are not marked in accordance with article 8 of this Protocol". 
There are two frequently overlapping types of illegal firearms markets: the grey one (wherein illegal traffic is carried out by or for governments), and the black one (wherein trades take place outside state control). ${ }^{2}$

Most weapons circulating in the black market come from the legal market and after diversion ${ }^{3}$ enter the illegal circuits. ${ }^{4}$ Illicit production (mostly by small-scale craftsmen) represents only a small share of the market. ${ }^{5}$ Conversely, authorized dealers, pawn shops, trade fairs and straw purchasers play a major role. ${ }^{6}$

The involvement of criminal organizations usually consists in the provision of transport services and the establishment of contacts with international brokers in importing countries. ${ }^{7}$ Firearms are distributed both by highly organized criminal networks operating internationally and by criminal entrepreneurs operating on a small scale and at local level. ${ }^{8}$

There are only a few studies on the illegal firearms market, with rough estimates of its size and proceeds, and no details on the methodologies used. ${ }^{9}$ This lack of knowledge also implies that there is no common methodology for its estimation. Nevertheless, a number of international studies estimate the illegal firearms market at between $10 \%$ and $20 \%$ of the legal market. ${ }^{10}$

\section{The illegal firearms market in Italy}

Italy is a transit country for illegal weapons being trafficked to Northern Europe, and it is located on the route that starts from the former Yugoslavian countries. ${ }^{11}$ An investigative report has revealed that $90 \%$ of illegal firearms in Rome originate from the Balkans (especially Croatia). ${ }^{12}$ Weapons are carried in hidden compartments in cars, vans and trucks. Other supply channels are thefts from apartments or from security guards. An interview with an informant showed that retail prices on the black market 
vary according to whether the firearm is new or second-hand (Table 1). ${ }^{13}$

Table 1. Retail prices of some firearms circulating on the black market in Rome. Prices in euros.

\begin{tabular}{lcc}
\hline Model & New & Second-hand \\
9x21 mm semi-automatic gun & 1,700 & 700 \\
$38 \mathrm{~mm}$ gun (special and revolver) & 1,400 & 700 \\
Rifle & 2,000 & $/$ \\
Sub-machine gun & 3,000 & 2,000 \\
\hline
\end{tabular}

Source: Angeli (2012)

The most recent reports by Italian law enforcement agencies emphasizes the involvement of both Italian mafias (Cosa Nostra, 'Ndrangheta, Camorra and Sacra Corona Unita) and foreign criminal organizations (Slav, Russian, Albanian and African) in the trafficking of illegal firearms. ${ }^{14}$ The Italian mafias operate not only as traffickers but also as buyers to support their illegal activities.

Only two sources provide rough estimates of the involvement of the mafias in the illegal firearms trade in Italy. ${ }^{15}$ Eurispes has estimated the 'Ndrangheta's revenues from illegal firearms at $€ 2.9$ bn in $2007 .{ }^{16}$ SOS Impresa has estimated the revenues for all the major Italian mafias (Cosa Nostra, 'Ndrangheta, Camorra and Sacra Corona Unita) at $€ 5.8$ bn. ${ }^{17}$ However, the two sources do not provide any details on the estimation methods. Furthermore, they focus only on the Italian mafias, although it is well known that other criminal actors are involved in the market. ${ }^{18}$ These features suggest that these figures should be treated with caution.

\subsection{The illegal counterfeit market}

According to European Union Regulation 1383 of 2003, goods are counterfeits when they bear "without authorization a trade mark which is identical to a validly registered trade mark, or which cannot be distinguished in its essential aspects from such trade mark". Drawing a distinction between the concepts of counterfeit and piracy is essential 
for investigation of the illegal counterfeit market. Counterfeiting concerns the unauthorized use of an unregistered trademark identical to a registered one. Piracy concerns goods that are unauthorized copies of products protected by intellectual property law. ${ }^{19}$

According to the World Customs Organization, the main destinations of seized counterfeits are the United States, Germany, Mexico, France and Japan. ${ }^{20}$ The main sources of counterfeits are in Asia, primarily China, Hong Kong and Taiwan. ${ }^{21}$ The most frequently seized products according to their value are clothing (16\%), cigarettes (11\%), sport shoes (10\%) and bags, wallets and purses $(9 \%) .^{22}$ The sea route is used in $81 \%$ of the shipments intercepted at the EU borders. ${ }^{23}$

The role of organized crime in management of the illegal market for counterfeit products is now widely recognized. Interest in this market began in the 1970s with the enlargement of the sphere of illegal activities controlled by these organizations. The demand for illegal products was becoming increasingly diversified, so that mafias were provided with an opportunity to increase their profits through counterfeiting. The products could be easily distributed via the channels already used for other illicit goods such as drugs and cigarettes. Allegedly, the mafias most involved in the counterfeit market are the Chinese Triads, the Japanese Yakuza, the Neapolitan Camorra and the Russian Mafia. $^{24}$

At the international level, a number of studies have been conducted on counterfeiting, piracy and intellectual property protection. ${ }^{25} \mathrm{~A}$ few of these studies have attempted to quantify counterfeiting, mainly by using seizure data. ${ }^{26}$ The value of the international market for counterfeit and pirated products in 2005 was estimated at around $\$ 200$ bn, excluding domestic production for domestic consumption and the volume of pirated digital products distributed via the internet. ${ }^{27}$ In 2007 , the OECD 
updated this estimate to $\$ 250 \mathrm{bn}^{28}$ The methodology for the estimation was based on seizure data and questionnaires administered to government agencies, customs, industries or business associations.

\section{The illegal market of counterfeit goods in Italy}

The illegal market of counterfeit goods in Italy is characterized by a close interaction between Italian and foreign mafias. ${ }^{29}$ The criminal groups most involved in this illegal market are the Chinese Triads, the Japanese Yakuza and the Neapolitan Camorra. ${ }^{30}$ According to a recent Europol report, the entry and the subsequent distribution of counterfeit goods in Italy is made possible by close cooperation between Chinese criminal groups and Italian mafias, among which the Camorra and the 'Ndrangheta seem to predominate. ${ }^{31}$

The counterfeits market has been estimated at between $5 \%$ and $10 \%$ of world trade, with a midpoint estimate of around 7\%, which is also in line with the WCO, the OECD and the European Commission estimates. ${ }^{32}$ The revenues of the Italian counterfeit market are estimated at $€ 7$ to $€ 8 \mathrm{bn}$. Confesercenti states that, in recent years, the volume of the market has almost doubled; more than $50 \%$ of the revenues are attributable to clothing and fashion, followed by music, audio-visual and software piracy. ${ }^{33}$ There are no details about the methodology of this study, although it appears to have been based on seizures, surveys, and other studies. In 2007, Confcommercio carried out a comprehensive data collection project. It used four focus groups to investigate the reasons for purchasing counterfeit products and conducted a survey of 2,000 CATI interviews to shed light on the market for counterfeit clothing, accessories and multimedia. It estimated the market at about $€ 3.3$ bn ( 2 for clothing, 1.2 for fashion accessories and 0.13 for multimedia products). ${ }^{34}$ Another study estimated the damage 
suffered by businesses and government revenues in Italy for 2001 by surveying companies from ten sectors at risk of counterfeiting. ${ }^{35}$ The damage to businesses was estimated at around $€ 4.2$ bn for 2001 , while the revenue losses were around $€ 1.5 \mathrm{bn} .{ }^{36} \mathrm{~A}$ study based on seizures by the Guardia di Finanza has estimated the counterfeits market at between $€ 3$ and $€ 5$ bn. ${ }^{37}$ CENSIS estimated a turnover of $€ 7.1$ bn in 2008 (domestic market only). The value comprises revenue losses, including direct and indirect taxes, at $€ 5.3 \mathrm{bn} .{ }^{38}$ The findings of most recent CENSIS report are consistent with these previous estimates, even if the domestic market has slightly decreased. In addition, it estimated that the legal production of an equal amount of goods would earn additional tax revenues of $€ 1.7 \mathrm{bn}$, whereas, on considering the induced production, it would be $€ 4.6$ bn, or $1.74 \%$ of the total state revenues from the relevant taxes. ${ }^{39}$

\subsection{The illegal gambling market}

"Gambling" includes different wagering systems such as casino games, bets, lotteries and gaming machines. Gambling is also a legal, though heavily regulated, business. Indeed, the literature focuses mostly on legal gambling and the relations with the commission of crimes. ${ }^{40}$ There are no studies assessing the proceeds of illegal gambling at the global or national level.

Illegal gambling often reflects the functioning of the legal market. For example, a study on illegal sports bookmakers showed that the illegal businesses were structured like legal ones and operated in a similar manner according to competitive market dynamics. ${ }^{41}$

Illegal gambling is often associated with organized crime, and it is claimed that criminal organizations have control over or monopolize the sector. Reuter and Rubinstein conducted a study to verify this claim by focusing on lotteries, betting and, 
to a lesser extent, loan sharking in New York. ${ }^{42}$ They demonstrated that the sector was not in fact controlled by organized crime. Liddick criticized their results, arguing that the role of organized crime is not so marginal and that there is no sharp distinction between legal and illegal activities, which are often arranged along a continuum of different levels of illegality. ${ }^{43}$

\section{Illegal gambling in Italy}

In Italy, the legal gambling market has expanded in recent decades due to the introduction of new games and services. In 2011 it generated a total of $€ 79.8 \mathrm{bn}$, of which approximately $€ 7-8$ bn consisted of taxes. The Autonomous Administration of State Monopolies (AAMS) is the Italian public agency responsible for management of the gambling sector and for the publication of data.

The growth of legal gambling has stimulated greater attention to its illegal side. This includes counterfeit games (such as "scratch and win" coupons), the management of unauthorized bet collection points, illegal lotteries, illegal gambling houses and the alteration of gaming machines. ${ }^{44}$ Various sources have highlighted the role of mafias in this sector. In a 2011 report, the Parliamentary Antimafia Commission analyzed mafia infiltration in legal and illegal gambling, ${ }^{45}$ finding that mafias manage bingo, clandestine casinos, gaming machines, illegal betting on football matches and horse racing, including online betting. ${ }^{46}$ Bets are managed primarily by unauthorized foreign bookmakers. Fake or irregular lotteries are also common means to launder money. ${ }^{47}$ In 2010 at least thirty law enforcement operations focused on gambling and organized crime (with arrests and seizures in a number of Italian cities). ${ }^{48}$ 
Among the various gambling systems, gaming machines are the most important, yielding $50-60 \%$ of the total takings from legal gambling. ${ }^{49}$ Currently, there are two main types of gaming machines: new slot machines and video lottery terminals (VLT). ${ }^{50}$

Several sources report the involvement of the Italian mafias and foreign criminal groups in illegal gaming machines. In particular, the three most important Italian mafias (Camorra, 'Ndrangheta and Cosa Nostra) have always shown an interest in control of such devices. ${ }^{51}$ The mafias control the installation and management of prohibited gaming machines, including the establishment of front companies, and they also force shops and premises to rent machines. ${ }^{52}$ Specifically, the National Antimafia Directorate 2011 report states: "the mafias, without abandoning their traditional gambling halls and organization of toto nero, have concentrated on the most lucrative sectors of gaming, and therefore mainly on the management and alteration of machines". ${ }^{53}$ The organization of gambling is also a typical activity of Chinese criminal organizations, which often use it as an extortion device, in particular towards Chinese nationals. ${ }^{54}$

The 2007 report by the Commissione Grandi ${ }^{55}$ estimated the number of illegal slot machines in 2006 at $200,000 .^{56}$ The report showed that two-thirds of the gaming machines were disconnected from the control network and achieved a turnover three times greater than that of devices controlled by the State. ${ }^{57}$ The Italian government reported that out of 87,050 inspected machines with cash prizes and 13,250 without cash prizes, 12,717 devices $(13 \%)$ were irregular. ${ }^{58}$ However, since the end of 2010 , the introduction of new types of gaming machines has led to a drastic reduction in the number of seizures, which in 2011 fell more than 6 times compared with $2009 .{ }^{59}$

Despite the alleged importance of the sector, there are no reliable estimates of its actual size. According to a dossier compiled by Libera, the turnover of organized crime from illegal gambling amounts to more than $€ 10$ bn ( $€ 2.5$ bn from football betting) ${ }^{60}$ 
Eurispes estimated the total volume of illegal gambling at around $€ 23$ bn, equaling $13.1 \%$ of the entire turnover of the illegal economy. ${ }^{61}$ Sos Impresa gauged the revenues from illegal gambling at more than $€ 4$ bn (€3.6 bn directly managed by mafias). ${ }^{62}$ The differences among these estimates show that the size of the Italian illegal gambling market is in fact still unknown. Furthermore, the above-mentioned estimates do not give any clear information on the methodology used, so that it is impossible to verify their reliability and accuracy.

\subsection{The illegal waste market}

Illegal activities related to the waste market are commonly defined as "any movement of waste which is not in accordance with environmental regulations" ${ }^{63}$ They include the illegal management (i.e. storage, transfer or disposal) of waste, as well as its illegal trafficking. ${ }^{64}$ At the same time, these activities may occur both domestically and internationally. ${ }^{65}$ The illegal waste market is particularly difficult to measure because, like its legal counterpart, it is characterized by different types of waste and different phases in the management cycle.

The illegal management and the illegal trafficking of waste are associated with several factors. The introduction of stricter regulations and the resulting increase in prices have been emphasized by many scholars, ${ }^{66}$ institutions ${ }^{67}$ and empirical studies. ${ }^{68}$ The demand for illegal waste management and disposal services almost always comes from legitimate businesses. ${ }^{69}$ Waste producers seek cheap services to minimize costs and maximize revenues, and the illegal market is able to provide these services. ${ }^{70}$ Some estimates have reported that, at the end of the 1980s, the average disposal cost of one ton of hazardous waste was between $\$ 100$ and $\$ 2,000$ in an OECD country and between \$2.5 and \$50 in Africa. ${ }^{71}$ More recently, Italian sources have suggested that prices in the 
illegal market are about one-fifth of those charged in the legal market. ${ }^{72}$ According to a study from the Netherlands, illegal prices would range between one-third and onefourth of the legal ones. ${ }^{73}$

This situation has resulted in the waste being transported from industrialized countries for illegal dumping in developing countries. Criminal groups operating the illegal waste trafficking seem to have relatively simple structures. Institutional sources and law enforcement agencies describe small groups of five to ten people, who often have ethnic links with the destination countries. ${ }^{74}$ At the same time, it seems that the sector has attracted the growing interest of organized crime groups, owing to the opportunity to make high profits at low risks. ${ }^{75}$ However, the actual involvement of traditional organized crime groups in the illegal trafficking of waste is still a matter of debate. $^{76}$

In general, no study has reliably estimated the size of the illegal waste market. Most of the available data refer to the legal movements of waste. ${ }^{77}$ Information on the illegal waste market comes primarily from seizures and surveillance efforts, incidents and other forms of crime reporting. However, they are not representative of the actual size of the illegal market and are often of poor quality. ${ }^{78}$

\section{Illegal waste management in Italy}

Italy is a rather specific case because of the significant participation of the Italian mafias in the waste market. ${ }^{79}$ In particular, the Camorra seems to be directly involved in illegal waste activities. Cosa Nostra and the 'Ndrangheta tend to use their intimidatory power and collusion with public officials to infiltrate the legal market. ${ }^{80}$ However, it would be a mistake to consider the illicit waste market in Italy as monopolized by the mafias. Individuals and companies not related with traditional mafias are equally involved in 
the illegal management and trafficking of waste. ${ }^{81}$ In many cases they are "white collar criminals", in particular entrepreneurs and brokers, but also chemists, engineers and analysts. ${ }^{82}$ These actors constitute what the Italian Antimafia Directorate (DNA) has recently called the "elite of illegal waste trafficking". ${ }^{83}$ Stable partnerships between this "elite" and the traditional mafias may, or may not, be established. Moreover, the illegal waste market has now extended nationwide, and can no longer be considered a localized problem limited to the regions of origin of the mafias. ${ }^{84}$

Owing to these specificities, Italy has become quite sensitive to the issue of "illegal waste" compared with other European countries. ${ }^{85}$ Since 2005 , a specific section of the DNA reports has focused on criminal activities related to the illegal management and trafficking of waste. Information on the "illegal waste cycle" is periodically provided also by the environmental organization Legambiente as part of its annual report "Ecomafia". Despite this attention, reliable estimates of the actual scale of the Italian illegal waste market do not exist. In 2011, Legambiente estimated the turnover from the illegal market of special waste at $€ 3.1 \mathrm{bn} .{ }^{86}$ However, this figure should be interpreted with caution, since it was calculated on the basis of the price of legal of waste management and disposal services and may thus have been overestimated. ${ }^{87}$ In fact, the illegal market can guarantee significant savings compared with the legal one.

\section{Methodologies}

Owing to the absence of reliable methodologies for the estimation of the four criminal markets, the study reported in what follows developed different solutions for each of them. 


\subsection{Estimating the revenues from the illegal firearms market}

The study calculated the revenues of the illegal firearms market using a supplybased and demand-based approach. Depending on the data available, estimates were calculated for 2010 at both the national and regional level.

The supply-based approach assumed that firearms seized/confiscated corresponded to $8 \%$ of the total market. ${ }^{88}$ Owing to the lack of figures on the firearms market, the assumption was based on the incidence of seizures in the volume of the drug market (between $8 \%$ and 10\%) and of the illicit tobacco market (10\% in 2009, $8 \%$ in 2010 and 5\% in 2011). ${ }^{89}$ The national illegal revenues were calculated as follows:

$$
\text { Illegal revenues Supply }=\frac{\text { N. of firearms seized } / \text { confiscated } \cdot 100}{8} \cdot € 1,579
$$

As regards demand, minimum and maximum values were produced. The demand-based approach assumed the illegal firearms market to be $10 \%$ or $20 \%$ of the legal market. This amount was determined by the value of exports (foreign demand), imports, and the turnover generated by the national market (domestic demand). ${ }^{90}$ Estimation was based on the following formulas:

Illegal revenues Demand $\min =($ Export + Import + Turnover Italian market $) \cdot 0,1$ Illegal revenues Demand $\max =($ Export + Import + Turnover Italian market $) \cdot 0,2$

National estimates were divided among the twenty Italian regions in proportion to their resident populations, according to the following formulas: ${ }^{91}$

$$
\text { Illegal revenues Supply }_{\text {reg }}=\frac{\text { Illegal revenues Supply }_{\text {nat }} \cdot \text { Population }_{\text {reg }}}{\text { Population }_{\text {nat }}}
$$

$$
\begin{aligned}
& \text { Illegal revenues Demand } \min _{\text {reg }}= \frac{\text { Illegal revenues Demand } \min _{\text {nat }} \cdot \text { Population }}{\text { reg }} \\
& \text { Illegal revenues Demand } \max _{\text {reg }}=\frac{\text { Population }_{\text {nat }}}{\text { Population }_{\text {nat }}}
\end{aligned}
$$


The regional revenues thus obtained were then adjusted to take account of the different incidence of the illegal market within each region. ${ }^{92}$ For this purpose, the regional illicit revenues were multiplied by the ratio between the rates of firearms seized/confiscated per 100,000 inhabitants at regional and national level. Estimates were calculated as follows: ${ }^{93}$

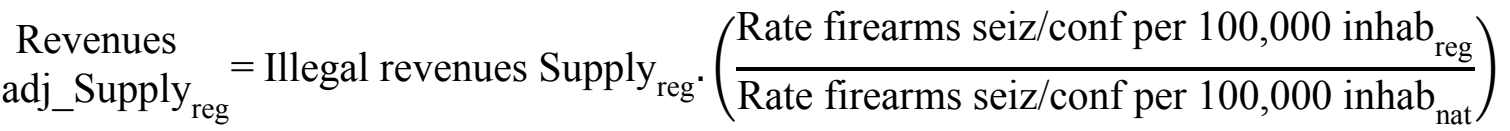

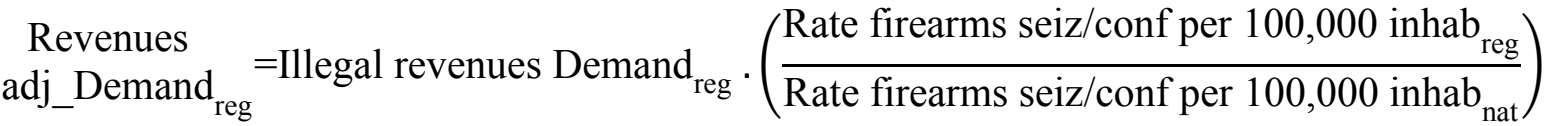




\subsection{Estimating the revenues from the illegal counterfeit market}

In general, studies estimating the counterfeit goods market have only calculated revenues based on the goods seized, or they have produced figures without specifying the methodology used. Given the lack of an established methodology in the literature, this study estimates the revenues of the illegal counterfeiting market by taking into account the turnover of companies in the sectors most at risk of counterfeiting and the workforce in those sectors. Estimates are for year 2008 due to the unavailability of more recent data. $^{94}$

The first step was identification of the economic sectors most at risk of counterfeiting in Italy and calculation of their legal annual turnovers. The analysis identified the categories of goods most at risk among those listed in the IPERICO database because they are more likely to be seized. IPERICO collects information on counterfeited goods by commodity macro-categories seized by the Italian law enforcement agencies. Each commodity macro-category listed in the IPERICO database was associated with an ATECO economic sector of the retail market in order to calculate the turnovers of the companies belonging to this economic sector and to estimate the total legal turnover of each sector at national level. ${ }^{95}$ Table 2 shows the various macro-categories listed in the IPERICO database, and the ATECO economic sectors that were connected to those categories to calculate the turnover of each sector in $2008 .{ }^{96}$ This calculation was performed for all the commodity macro-categories $s$ :

$$
\text { Legal Market }_{\mathrm{s}}=\sum \text { Company turnover } \in \mathrm{s}
$$


Table 2. IPERICO product groups and corresponding ATECO economic sectors

PRODUCT GROUP

Clothing

Accessories of clothing

Footwear

Electrical equipment

IT equipment

CD, DVD, tape

Toys

Glasses

Watches and jewels

Perfumes and cosmetics
CORRESPONDING ATECO SECTOR

4,771: retail sale of clothing in specialized shops

4,772: retail sale of footwear and leather items in specialized shops

4,782: retail street sale of textiles, clothing and footwear

4,754: retail sale of electrical equipment in specialized shops

4,741: retail sale of computers, peripheral devices, software and office equipment in specialized shops

4,763: retail sale of music and video recordings in specialized shops

4,765: retail sale of toys in specialized shops

32,504: production of ophthalmic lenses

32,505: production of frames of different types; mass-produced frames of ordinary glasses

4,777: retail sale of watches and jewels in specialized shops

4,775: retail sale of cosmetics, perfumes and herbalist items in specialized shops

The second step consisted in calculating $5 \%$ and $10 \%$ of the total legal turnover

of each sector. Indeed, according to the literature, the counterfeit market has a global value of between $5 \%$ and $10 \%$ of the total trade. These figures enabled calculation of the minimum and maximum estimates of the total illegal revenues for each commodity macro-category at national level, as the following formulas summarize:

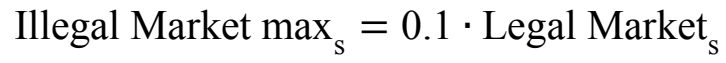

$$
\begin{aligned}
& \text { Illegal Market } \min _{\mathrm{s}}=0.05 \cdot{\text { Legal } \text { Market }_{\mathrm{s}}}
\end{aligned}
$$

In the third step, the national estimates by commodity macro-category were redistributed among the twenty Italian regions using the number of employees and considering each ATECO economic sector at regional level in 2007. It was assumed that the regions with the highest number of employees also have larger markets, both legal and illegal. Calculation was made of the percentage of the number of employees in each region by commodity macro-category on the total number of employees by category at national level, in order to identify which regions have the highest and which the lowest number of employees. The different percentages were then multiplied by the total value of the illegal national market, first according to the lowest estimate of 5\% and then according to the maximum estimate of $10 \%$, as shown by the following 
formulas:

$$
\begin{aligned}
& {\text { Illegal Market } \max _{\mathrm{s} \text {, reg }}}=\frac{\text { No. employees }_{\mathrm{s} \text {, reg }}}{\text { No. employees }_{\mathrm{s} \text {, nat }}} \cdot \text { Illegal Market max }_{\mathrm{s}} \\
& {\text { Illegal Market } \min _{\mathrm{s}, \text { reg }}}=\frac{\text { Num. employees }_{\mathrm{s}, \text { reg }}}{\text { Num. employees }_{\mathrm{s} \text {, nat }}} \cdot \text { Illegal Market min }_{\mathrm{s}}
\end{aligned}
$$

\subsection{Estimating the revenues from the illegal gambling market}

Considering the variety of illegal gambling activities and the lack of data on them, the study opted to focus exclusively on illegal gaming machines. This decision appeared acceptable in various respects. First, in 2011 gaming machines generated a turnover of $€ 44.8$ bn, which was more than $56 \%$ of the total turnover from legal gambling (€79.8 bn). Lotteries followed at a distance, with $€ 10.1 \mathrm{bn} .{ }^{97}$ Second, the DNA has recently stressed the crucial role of revenues from new slot machines and VLT machines for criminal organizations, suggesting that this may become the largest portion of the illicit gambling market. ${ }^{98}$ Finally, data on gaming machines are periodically published by AAMS. Given that the gambling supply is constantly changing, it was considered appropriate to limit the estimate to 2011, the most recent year for which data were complete. The choice of that year also made it possible to estimate the illicit market after the introduction of the new gaming machines: 2011 was the first year in which, in addition to new slot machines, also VLT machines were introduced.

Estimation of the revenues from illegal gambling machines in 2011 moved through various stages. First calculated were the regional takings for new slot machines and VLTs. The national legal takings (total cash collected) from gaming machines of each type were distributed among the twenty Italian regions according to the ratio between the total regional takings and the total national takings: ${ }^{99}$ 
Takings new slots $_{\text {reg }}=\frac{\text { Takings new slots }_{\text {nat }} \cdot \text { Total takings }_{\text {reg }}}{\text { Total Takings }{ }_{\text {nat }}}$

Takings VLTs $_{\text {reg }}=\frac{\text { Takings VLTs }_{\text {nat }} \cdot \text { Total takings }_{\text {reg }}}{\text { Total Takings }{ }_{\text {nat }}}$

Second, the study calculated the infringement rate. This was given by the ratio between the number of not merely-formal infringements and the number of machines inspected. $^{100}$

$$
\text { Infringement rate }_{\text {reg }}=\frac{\text { not merely formal infringements }}{\text { reg }}
$$

Third, the product of the infringement rate and the regional takings provided the regional illicit takings. ${ }^{101}$ The turnover was calculated in a differentiated way for new slot machines and VLTs.

$$
\begin{gathered}
\text { Illegal Takings new slots }_{\text {reg }}=\text { Infringement rate }_{\text {reg }} \cdot \text { Takings new slots }_{\text {reg }} \\
\text { Illegal Takings VLTs } \\
\text { reg }
\end{gathered}
$$

Fourth, the illegal revenues were derived from illegal takings. This derivation was based on a minimum and maximum hypothesis on the subdivision of the takings. In the legal market, takings from gaming machines are distributed as follows: payouts are determined by law (75\% of takings for new slot machines and $85 \%$ for VLTs); $0.8 \%$ equal to the concession fee; state taxation (between $4 \%$ and $13 \%$ of takings); the rest is divided among distributors, managers, and retailers on the basis of private contracts. ${ }^{102}$ The minimum estimate hypothesized that illegal machines may evade only part of the taxation and/or that a part of the takings would be distributed among retailers and 
distributors. Accordingly, it assumed that revenues amount to $20 \%$ for new slot machines and $10 \%$ for VLTs. The maximum estimate assumed that illegal machines pay no taxes, no fees to retailers and distributors, and even have reduced payout rates (not excessively, since it may inhibit the players and be suspicious). In this case, revenues may be as high as $30 \%$ of the illegal takings for new slots and $20 \%$ for VLTs.

$$
\begin{aligned}
& \text { Illegal Revenues new slots max }_{\text {reg }}=0.3 \cdot \text { Illegal Takings new slots }_{\text {reg }} \\
& \text { Illegal Revenues new slots } \min _{\text {reg }}=0.2 \cdot \text { Illegal Takings new slots }_{\text {reg }} \\
& \text { Illegal Revenues VLTs max }_{\text {reg }}=0.2 \cdot \text { Illegal Takings VLTs }_{\text {reg }} \\
& \text { Illegal Revenues VLTs min }_{\text {reg }}=0.1 \cdot \text { Illegal Takings VLTs }_{\text {reg }}
\end{aligned}
$$

The sum of max/min revenues from both types of machines yielded the maximum and minimum revenues from the illegal gaming machines market.

Total Ill Rev max reg Ill Rev new slots max ${ }_{\text {reg }}+$ Ill Rev VLTs max reg Total Ill Rev min $\operatorname{reg}_{\text {re }}=$ Ill Rev new slots $\min _{\text {reg }}+$ Ill Rev VLTs min reg

\subsection{Estimating the revenues from the illegal special waste market ${ }^{103}$}

The methodology used to estimate the illegal waste market drew in part on the approach developed by Legambiente, and it focused on the difference between legal waste production and management, assuming that this difference may be imputable to the illegal market. The estimation was limited to special waste and did not consider municipal waste, mostly entrusted to public companies, but also frequently infiltrated by the mafias (e.g. the infamous waste emergencies in Naples and Palermo). ${ }^{104}$ This methodological choice was made for various reasons. First, in 2010 (last available year) 
special waste represented more than $80 \%$ of the total waste produced in Italy. Municipal waste, by contrast, accounted for less than $20 \% .{ }^{105}$ Second, the illegal management of special waste seems to be particularly attractive to criminal operators, since it guarantees higher profits than the municipal waste. ${ }^{106}$ Finally, data on the production and management of special waste are periodically released by the Italian Institute for Environment Protection and Research (ISPRA). ${ }^{107}$

The study estimated the volume and revenues of the illegal market of special waste for the period 2007-2010 (mean of the four years). The estimates were performed at both the national and regional level, and they distinguished between hazardous and non-hazardous waste. The estimation consisted of various steps.

First calculated was the legal management at regional level, i.e. the amount of special waste managed by legitimate facilities in each region $\left(\mathrm{LM}_{\mathrm{reg}}\right)$. The legal management was calculated as the sum of the special waste subject to final operations of recovery and disposal and the stock. The stock was the difference between stored waste in a given year and stored waste in the previous year: ${ }^{108}$

$$
\begin{gathered}
\mathrm{LM}_{\text {reg }_{\mathrm{t}}}=\text { Final Manag }_{\text {reg }_{\mathrm{t}}}+\text { Stock }_{\text {reg }_{\mathrm{t}}} \\
\text { Stock }_{\text {reg }_{\mathrm{t}}}=\text { Stored waste }_{\text {reg }_{\mathrm{t}}}-\text { Stored waste }_{\text {reg }_{\mathrm{t}-1}}
\end{gathered}
$$

Second the legal management was adjusted on the basis of the amount of waste produced in each region ( $\mathrm{LMadj}_{\text {reg. }}$.). ${ }^{109}$ Two different coefficients were used, depending on the type of waste (hazardous/non-hazardous). For non-hazardous waste, the geographical macro-area (Northern, Central and Southern Italy) was considered. ${ }^{110}$ With regard to hazardous waste, the national figure was used. ${ }^{111}$

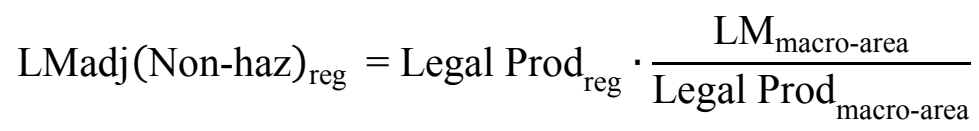

$$
\begin{aligned}
& \operatorname{LMadj}(\mathrm{Haz})_{\text {reg }}=\text { Legal Prod }_{\text {reg }} \cdot \frac{\mathrm{LM}_{\text {nat }}}{\text { Legal Prod }_{\text {nat }}}
\end{aligned}
$$


The volume of the illegal market $\left(\mathrm{IM}_{\mathrm{reg}}\right)$ was then estimated as the difference between legal production and legal management adjusted.

$$
\begin{aligned}
& \text { IM (Non-haz) } \left.)_{\text {reg }}=\text { Legal Prod }_{\text {reg }}-\text { LMadj }_{(\text {Non-haz }}\right)_{\text {reg }} \\
& \left.\mathrm{IM}(\mathrm{Haz})_{\text {reg }}=\text { Legal Prod }_{\text {reg }}-\text { LMadj }_{(\mathrm{Haz}}\right)_{\text {reg }}
\end{aligned}
$$

Fourth, multiplying the illegal market by the average price of the legal services of waste management yielded the revenues of the illegal market at legal prices (Rev LPr) for both types of waste (hazardous/non-hazardous). ${ }^{112}$

$$
\begin{gathered}
\text { Rev LPr(Non-haz } \left.)_{\text {reg }}=\text { IM (Non-haz }\right)_{\text {reg }} \cdot € 90,5 \\
\text { Rev LPr } \left.(\text { Haz })_{\text {reg }}=\text { IM (Haz }\right)_{\text {reg }} \cdot € 305
\end{gathered}
$$

The sum of the two yielded the revenues of the illegal special waste market at legal prices.

$$
\text { Rev LPr } \left.\text { TOT }_{\text {reg }}=\text { Rev LPr(Non-haz }\right)_{\text {reg }}+\operatorname{Rev~LPr~}(\mathrm{Haz})_{\text {reg }}
$$

However, the literature suggests that the illegal market can guarantee significant savings. In particular, it seems that prices in the illegal market are between one-third and one-fifth of the legal ones. The revenues of the illegal market at legal prices were therefore divided by 3 (maximum value) and by 5 (minimum value) to calculate the revenues of the illegal waste market (Rev IM).

$$
\begin{aligned}
& \text { Rev IM } \max _{\text {reg }}=\frac{\text { Rev LPr TOT }}{\text { reg }} \\
& \text { Rev IM } \min _{\text {reg }}=\frac{\text { Rev LPr TOT }}{\text { reg }} \\
& 5
\end{aligned}
$$

The maximum and minimum estimates were calculated for non-hazardous waste, hazardous waste, and the total. 


\subsection{Limitations}

Given the lack of previous estimations in the literature, the estimates of the four illegal markets should be considered as exploratory and, as such, treated with particular caution. Indeed, they have a number of limitations.

First, owing to the lack of previous research, in some cases it was necessary to adopt assumptions and hypotheses without adequate empirical bases. ${ }^{113}$

Data availability and reliability was a second major issue. The retrieval, interpretation and analysis of data generated numerous difficulties and problems. Available data were scarce, and it is for this reason that some estimates date back to 2010 (firearms), 2008 (counterfeiting) and 2007-2010 (waste).

Third, the scarcity of data sometimes required the use of data on seizures and confiscations. These sources are particularly problematic, since they may frequently represent proxies for law enforcement activity/efficiency rather than for the illegal activities. Whenever possible, inspection was made of the distribution of such data to verify whether they were excessively biased towards measurement of law enforcement performance. For example, data on seized counterfeit goods were excluded from the analysis because they were more representative of the trend in controls than in counterfeiting itself.

For the above reasons, estimation of the revenues from the four illegal markets was conducted with particular caution, and it always included a minimum and maximum estimate.

Overall, these considerations suggest that the estimates should be treated as first attempts to measure a particularly obscure set of criminal activities. Future estimations will have to refine the methodologies and address the above-mentioned limitations in order to gain better understanding of these illegal markets and provide more precise 
figures. Data availability and reliability will probably be the greatest challenge.

Undoubtedly, new data are greatly needed to raise the accuracy of the estimations to the levels of those on other illegal activities.

\section{Results and discussion}

Table 3. Minimum and maximum estimates of the revenues of the markets for illegal firearms (year 2010), counterfeit goods (year 2008), gaming machines (year 2011) and special waste (years 2007-2010) (mn €).

\begin{tabular}{lcccccccc} 
& \multicolumn{2}{c}{ Firearms } & \multicolumn{2}{c}{ Counterfeiting } & \multicolumn{2}{c}{ Gambling } & \multicolumn{2}{c}{ Waste } \\
& Min & Max & Min & Max & Min & Max & Min & Max \\
Abruzzo & 1.02 & 2.51 & 65.9 & 131.9 & 2.00 & 3.20 & 5.83 & 9.72 \\
Basilicata & 0.72 & 1.99 & 22.3 & 44.5 & 6.62 & 10.58 & 2.65 & 4.41 \\
Calabria & 2.58 & 7.78 & 79.7 & 159.4 & 21.15 & 33.83 & 4.65 & 7.76 \\
Campania & 5.89 & 16.26 & 283.6 & 567.2 & 47.07 & 75.28 & 17.26 & 28.77 \\
Emilia- & 2.68 & 6.81 & 248.5 & 497.1 & 4.41 & 7.06 & 22.12 & 36.87 \\
Romagna & & & & & & & & \\
Friuli-V.G. & 1.00 & 2.60 & 80.9 & 161.9 & 6.57 & 10.50 & 7.97 & 13.29 \\
Lazio & 2.32 & 13.03 & 289.5 & 579.1 & 22.02 & 35.22 & 25.17 & 41.95 \\
Liguria & 2.05 & 5.31 & 82.5 & 165.1 & 0.38 & 0.60 & 6.51 & 10.84 \\
Lombardy & 3.57 & 11.01 & 514.3 & 1028.6 & 12.78 & 20.44 & 37.86 & 63.10 \\
Marche & 1.05 & 3.00 & 68.6 & 137.1 & 2.13 & 3.41 & 12.42 & 20.71 \\
Molise & 0.35 & 0.93 & 12.6 & 25.1 & 0.50 & 0.80 & 2.32 & 3.87 \\
Piedmont & 2.41 & 7.67 & 197.2 & 394.5 & 44.85 & 71.72 & 17.13 & 28.54 \\
Apulia & 4.16 & 15.85 & 171.2 & 342.4 & 40.60 & 64.92 & 24.95 & 41.58 \\
Sardinia & 1.04 & 3.14 & 67.3 & 134.6 & 39.75 & 63.57 & 11.27 & 18.78 \\
Sicily & 4.17 & 10.75 & 205.0 & 410.1 & 64.16 & 102.61 & 21.72 & 36.20 \\
Tuscany & 4.36 & 12.11 & 189.2 & 378.4 & 6.46 & 10.32 & 37.92 & 63.19 \\
Trentino-A.A. & 0.24 & 1.79 & 52.9 & 105.9 & 0.3 & 0.4 & 8.28 & 13.80 \\
Umbria & 1.62 & 4.77 & 40.3 & 80.7 & 1.44 & 2.30 & 8.40 & 14.00 \\
Valle d'Aosta & 0.03 & 0.12 & 5.3 & 10.7 & 1.20 & 1.92 & 0.53 & 0.88 \\
Veneto & 4.78 & 13.46 & 350.5 & 700.9 & 2.60 & 4.16 & 29.05 & 48.42 \\
Italy & 46.07 & 140.87 & 3027.5 & 6055.0 & 326.69 & 522.44 & 304.01 & 506.68 \\
Source: authors' & elaboration & & & & & & &
\end{tabular}

The estimated revenues from the illegal firearms market ranged between $€ 46 \mathrm{mn}$ and $€ 141 \mathrm{mn}$ in 2010 (Table 3). The minimum estimate is the result of the supply-based approach, while the demand-based approach provided higher values (between $€ 70$ and $€ 141 \mathrm{mn}$, see also Table 4). In both cases, these figures are significantly lower than the estimates provided by previous studies, which have assessed the revenues of the illegal firearms market at between $€ 2.9$ and $€ 5.8$ bn (see 2). This remarkable discrepancy is difficult to explain in the absence of any information concerning the sources, 
methodologies, and data used for the previous estimations. These figures appear to grossly overestimate the Italian illicit firearms market. As already mentioned, the total turnover of Italian firearms production (including ammunitions) was approximately $€ 468 \mathrm{mn}$ in 2010 , of which only $€ 115 \mathrm{mn}$ came from the domestic market. If correct, the estimations from the above-mentioned sources would make the illegal market approximately twenty-five to fifty times larger than the legal one. This consideration suggests that the previous sources may have merely reported such figures with no verification of their reliability.

As regards the regional figures, the highest values are recorded among the most populated regions, which are also characterized by remarkable ratios of firearms seizures and confiscations. This is due to the methodological approach adopted for the estimation, which was based on the assumption that the illicit market is larger where there are more inhabitants and more firearms seized/confiscated. This may have determined only a rough representation of the actual revenues of the illegal firearms market across the Italian regions. Future studies should seek to improve this representation, possibly by gathering better empirical evidence on the concentration of the illicit firearms trade at the regional level. As already argued (see 3.5), data availability and reliability will raise the greatest challenges. 
Figure 1 - Estimates of the revenues from the illegal firearms market by region $(\mathrm{mn} €)$. Year 2010. Absolute values and rates per 100,000 inhabitants.
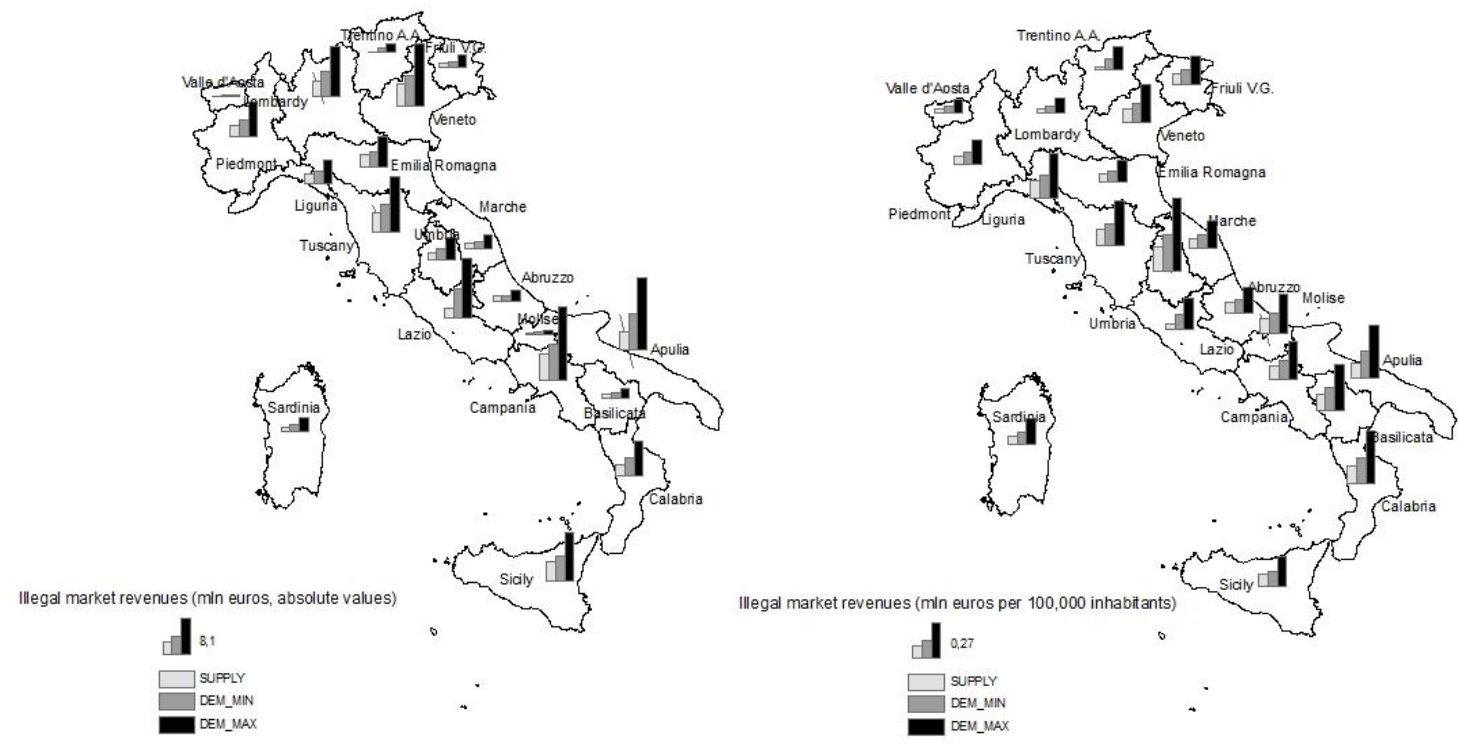

Source: authors' elaboration

The revenues of the market of counterfeit goods range between $€ 3,028 \mathrm{mn}$ (minimum) and $€ 6,055 \mathrm{mn}$ (maximum) in 2008 (Table 3). Overall, the figures are broadly comparable with previous estimates. The results are lower than the assessments by Confesercenti and CENSIS (€7,000-€8,000 mn), whereas they are almost in line with those of a study by the Guardia di Finanza which evaluated the counterfeit market at between $€ 3,000$ and $€ 5,000 \mathrm{mn}$. It is difficult to explain the differences among these estimates owing to the lack of detailed information on the methodologies used by the previous studies. Despite these differences, in accordance with the findings in the literature, the sector yielding the highest illicit revenues is clothing, accessories and footwear, with a minimum estimate of $€ 1,854 \mathrm{mn}$ and a maximum estimate of $€ 3,708$ mn (Table 4).

The regional figures seem to confirm that the illegal counterfeit market in Italy is widespread across the country. Taking the absolute values into account, the regions recording the highest estimates are Lombardy, Veneto, Campania and Lazio, whereas 
according to the rate per 100,000 inhabitants the phenomenon is widespread across the entire country (Figure 2). In part, these results may be biased by the assumptions made for the estimation procedure. The regional figures are based on the number of employees in each sector and region, assuming that regions with the highest number of employees in one sector may also have a more prosperous and larger market in that sector, both legal and illegal. Further research should improve the distribution of the illicit revenues across regions, with better identification of the variables that can affect the counterfeit market at the local level.

Figure 2 - Estimates of the revenues from the illegal counterfeit market by region (mn $€)$. Year 2008. Absolute values and rates per 100,000 inhabitants.
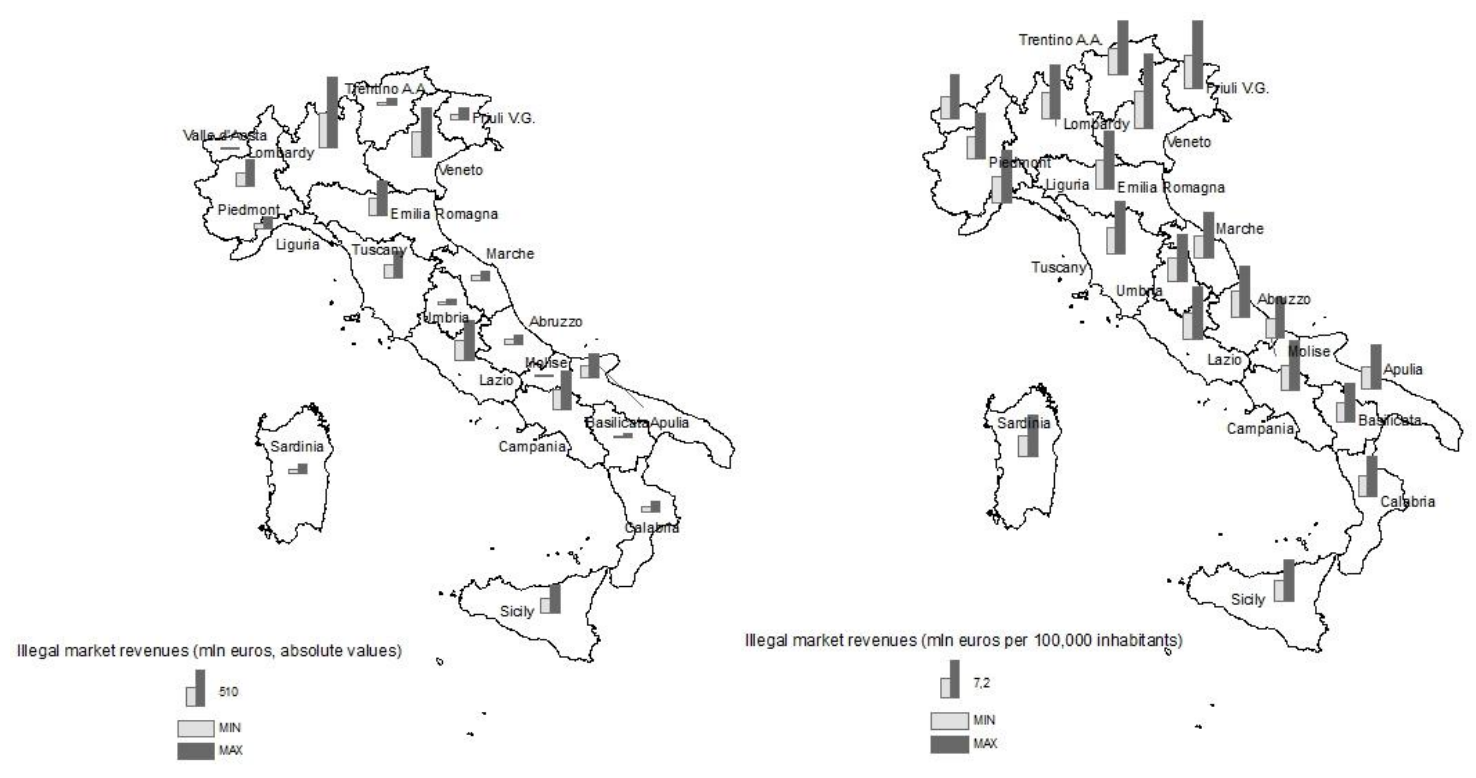

Source: authors' elaboration

The estimated revenues from illegal gambling machines ranged between $€ 326$ and $€ 522$ $\mathrm{mn}$ in 2011 (Table 3). The figures are remarkably below the alleged revenues reported by other sources, which covered the entire illegal gambling sector (see above in 2.3). The difference may be due to a number of factors. 2011 was the first year in which a significant number of VLT machines were operational. These devices had better control systems and were more difficult to tamper with. Analysis of controls and seizures 
suggests that irregularities have decreased with VLTs, and the estimated illegal revenues may have been higher in previous years. Moreover, the limited information on the methodology used by other sources suggests that these may have been based mostly on heterogeneous law enforcement and institutional material. Finally, the present study has only focused on a specific type of illegal gambling, excluding other potentially profitable subsectors (e.g. illegal football betting).

In regard to the regional distribution, Southern regions, Piedmont and Valle d'Aosta have the highest rates, due to higher violations/controls ratios (Figure 3). For some traditional mafia regions this may be due to the presence of organized crime. The figure is more surprising in the case of Sardinia, which ranks first for illegal revenues (with a remarkably high violations/controls ratio, second only to Sicily). Further analyses should focus on these regions in order to identify and verify possible causes of the higher prevalence of illegal gambling.

Figure 3 - Estimates of the revenues from illegal gaming machines by region $(\mathrm{mn} €)$. Year 2011. Absolute values and rates per 100,000 inhabitants.
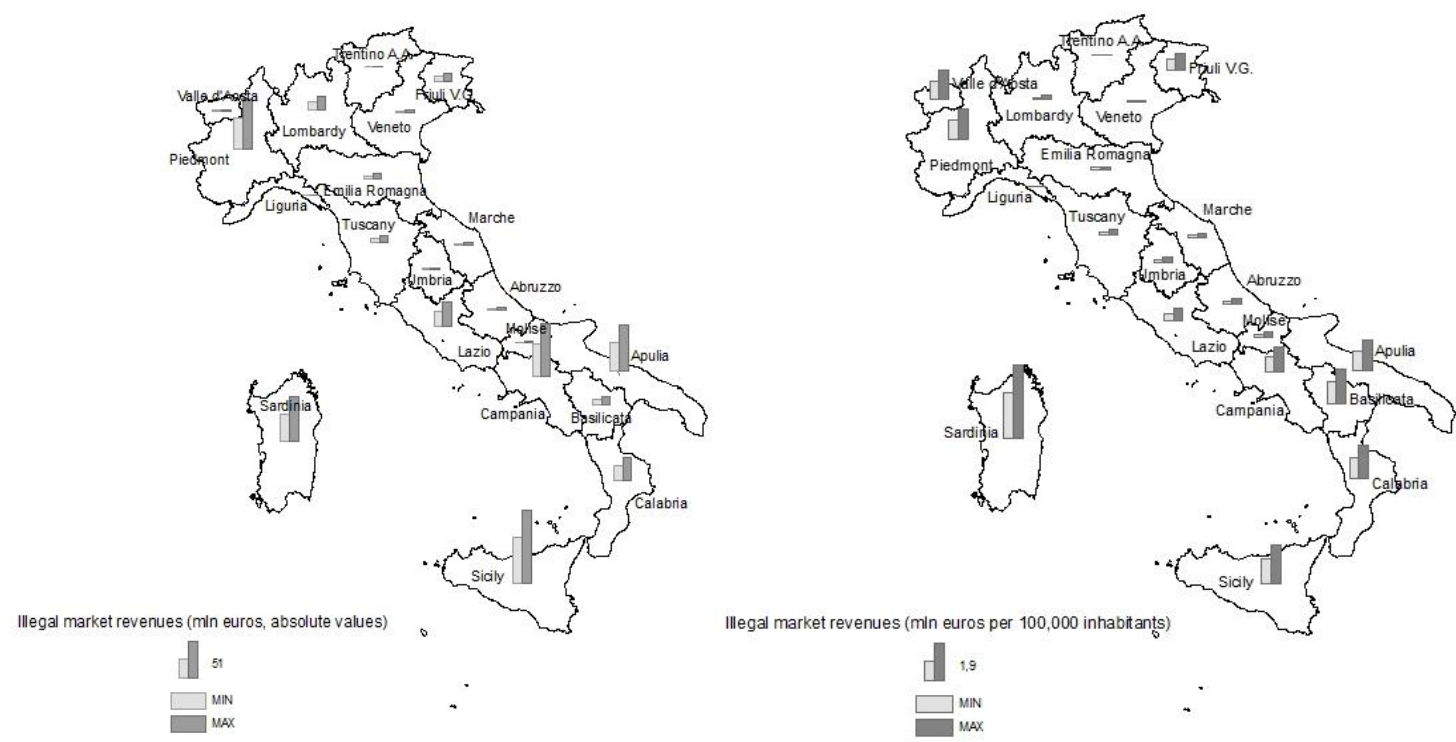

Source: authors' elaboration

The estimated national revenues from the illegal market of special waste range between 
$€ 304$ and $€ 507 \mathrm{mn}$ (Table 3). The bulk of these revenues (between $€ 279$ and $€ 466 \mathrm{mn}$ ) is attributable to non-hazardous waste. Conversely, hazardous waste generated illegal revenues amounting to between $€ 25$ and $€ 41 \mathrm{mn}$ (see Table 4). This disproportion reflects the methodological approach adopted for the estimation, which focused on the difference between legal waste production and management. Non-hazardous waste represented much the largest amount (around 92\%) of the special waste produced in Italy in the time period considered. Accordingly, the corresponding revenues are higher than those from hazardous waste.

The national figures are significantly lower than the estimates provided by previous studies (see 2.4). This discrepancy may be due to the fact that the previous estimates were based on legal prices of waste management and disposal. However, these prices are generally higher than those charged by the illegal market. At the same time, the illegal management and disposal of waste do not incur the same operating expenses as their legal counterparts. ${ }^{114}$ It can therefore be argued that large part of the estimated revenues from the illegal waste market result in direct profits for the illegal actors. Unfortunately, the actual scale of these profits is difficult to estimate owing to the lack of reliable data.

The regional figures seem to confirm that the illegal waste market in Italy has extended nationwide (Figure 4). However, the estimation process "leveled out" the regional values on the basis of those in the macro-area or at national level, depending on the type of waste (see 3.4). This may have resulted in a poor representation of the actual levels of the illegal waste market across the Italian regions. Future research should address the limitations of the present study in order to provide better understanding of the regional distribution of illegal waste activities, as well as a first evaluation of the 
profits associated with this market. Also for this illicit market, the greatest challenges will probably be data availability and reliability.

Figure 4 - Estimates of the revenues from illegal waste market by region (mn $€$ ). Average years 2007-2010. Absolute values and rates per 100,000 inhabitants.
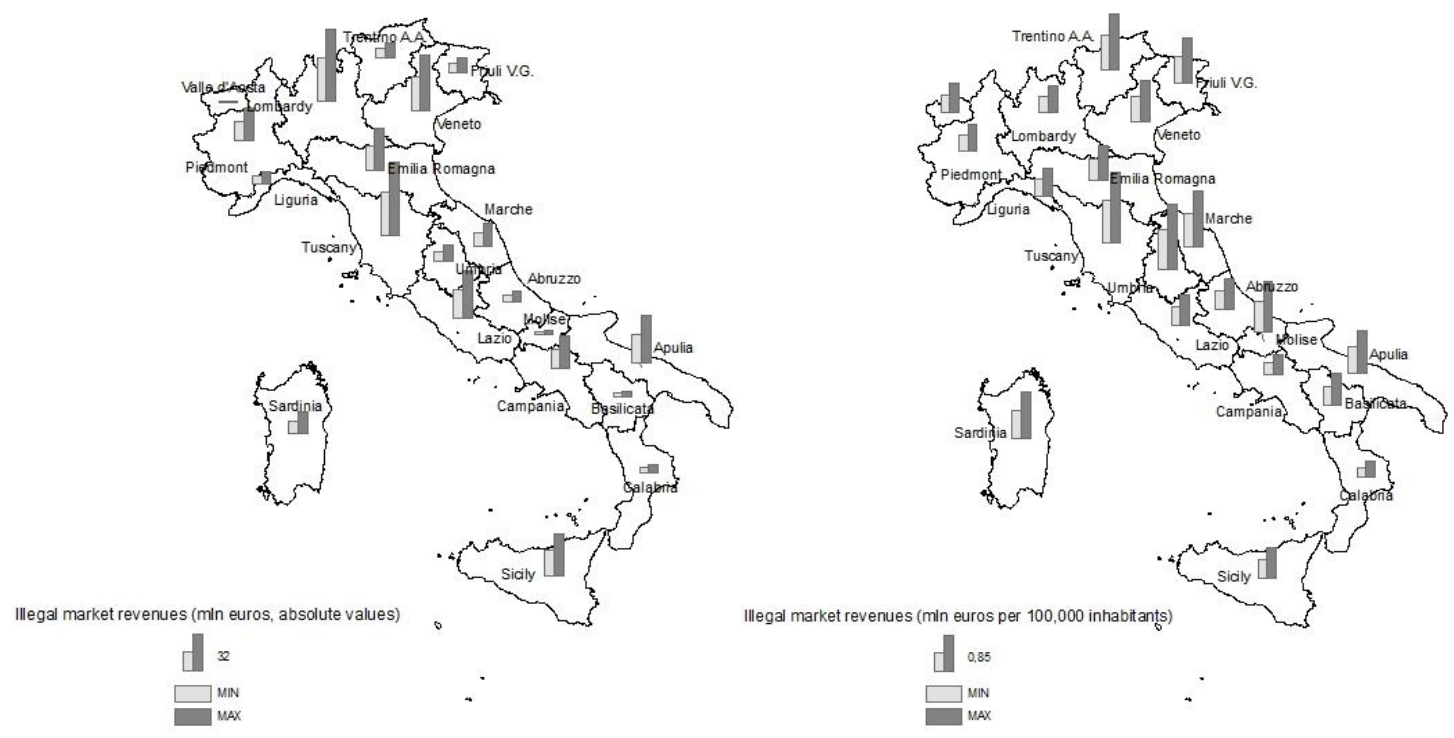

Source: authors' elaboration

\section{Conclusions}

This article has explored the possibilities of estimating four illegal markets, with the focus on Italy. Considering the lack of previous reliable assessments on any of these four criminal activities, this study should be treated as exploratory. Its goal has been to stimulate debate, at the international and national levels, on the frequently overestimated figures recurrently publicized by the media, and on the various ways to produce more reliable estimations.

Despite the clear differences among the four markets analyzed in this study, there are common features in regard to estimation of their revenues. First, there is a remarkable absence of reliable data. The availability of seizure data does not solve the problem, since these data are not optimal for the measurement of criminal activities across different regions. They may depend more on the performance of, or the resources 
available to, the law enforcement agencies, or on the entry points of illicit products. For this reason, the estimations excluded seizures and confiscations when estimating the total revenues for all four activities, except for the supply-based approach in the illicit firearms market. In some cases, seizures were used to distribute the criminal revenues at the regional level. Besides seizure data, there is a lack of yearly available and reliable data enabling measurement of the size of the illicit markets, with the possible exception of the tobacco industry's empty pack surveys. Improvement of data collection is crucial for better and replicable estimates of the criminal markets. It is a necessary condition for monitoring their trends and measuring the efficiency of preventive and repressive policies.

Second, despite the dearth of data, a number of different estimates of the four markets circulate in official reports and in the media. All these assessments lack details about the methodologies and the data used. This makes it very difficult to verify and compare these figures with the results of new studies. Furthermore, it raises suspicions as to their reliability, especially when the figures clearly overestimate the proceeds of these crimes. These figures are interesting examples of mythical numbers (i.e. overestimations of a social phenomenon with no empirical support, gaining authority due to repetition). ${ }^{115}$ In the criminal markets of this study, these numbers may be created no only by public agencies (e.g. law enforcement agencies seeking additional resources), but also by the legal industries (e.g. to get increased police attention and inflate the value of their brand). Particularly in the case of firearms and waste, the previous figures appear to be gross over-calculations of the sizes of the markets. For example, the alleged yearly revenues from illicit firearms trafficking would be between twenty-five and fifty times the national demand for firearms and ammunition from the legitimate market. This trend in the diffusion of unreliable estimates is problematic 
because it contributes to the dissemination of stereotypes on the mafias. Like the lack of information, also the diffusion of wrong figures may jeopardize public and private action against the mafias and impair the allocation of law enforcement resources.

In conclusion, while not claiming to provide definitive estimates, this study has adopted carefully described and replicable methodologies with which to measure the revenues of the illicit markets for firearms, counterfeits, gaming machines and special waste. This is a necessary step towards improving knowledge on these frequently debated, but rarely measured, criminal activities.

\section{References}

Albrecht, Hans-Jörg. "The Extent of Organized Environmental Crime. A European Perspective.” In Environmental Crime In Europe: Rules of Sanctions, edited by Françoise Comte and Ludwig Krämer. Groningen: Europa Law Publishing, 2004.

Angeli, Federica. "Pistole, Kalashnikov, Persino Un Missile Grandi Affari Al

Supermarket Dei 'Ferri."” Inchieste - La Repubblica, 2012.

http://inchieste.repubblica.it/it/repubblica/reproma/2012/02/21/news/pistole_kalashnikov_persino_un_missile_grandi_affari_ al_supermarket_dei_ferri-30261014/.

CENSIS. "Comunicati stampa - CENSIS,” 2009. http://www.censis.it/10?resource_50=5717\&relational_resource_51=5717\&relat ional_resource_385=5717\&relational_resource_52=5717\&relational_resource_3 81=5717\&relational_resource_382=5717\&relational_resource_383=5717\&relati onal_resource_384=5717.

_. L'impatto della contraffazione sul sistema-Paese: dimensioni, caratteristiche e approfondimenti. Roma: Ministero dello Sviluppo Economico, 2012.

Confesercenti. Contraffazione e criminalità informatica: i danni all'economia e alle imprese. Roma: Confesercenti, 2007.

Cornish, Derek Blaikie. Gambling: A Review of the Literature and Its Implications for Policy and Research. London: Home Office, 1978. 
CPA. Relazione sul fenomeno delle infiltrazioni mafiose nel gioco lecito ed illecito. Roma: Commissione parlamentare d'inchiesta sul fenomeno della mafia e sulle altre associazioni criminali, anche straniere, 2011.

Cukier, Wendy. The Illicit Trade in Small Arms: Addressing the Problem of Diversion. Waterloo, Canada: Small Arms Working Group, 2008. http://www.muntr.org/v4/wp-content/uploads/2012/02/ADDRESSING-THEPROBLEM-OF-DIVERSION.pdf.

DIA. Relazione del Ministro dell'Interno al Parlamento sull'attività svolta e sui risultati conseguiti dalla Direzione Investigativa Antimafia: Secondo semestre 2010. Roma: Direzione Investigativa Antimafia, 2010.

—. Relazione del Ministro dell'Interno al Parlamento sull'attività svolta e sui risultati conseguiti dalla Direzione Investigativa Antimafia: Secondo semestre 2011. Roma: Direzione Investigativa Antimafia, 2011. http://www.interno.it/dip_ps/dia/semestrali/sem/2011/1sem2011.pdf.

DNA. Relazione annuale sulle attività svolte dal Procuratore nazionale antimafia e dalla Direzione nazionale antimafia nonché sulle dinamiche e strategie della criminalità organizzata di tipo mafioso nel periodo $1^{\circ}$ luglio $1999-30$ giugno 2000. Roma: Direzione Nazionale Antimafia, 2000.

. Relazione annuale sulle attività svolte dal Procuratore nazionale antimafia e dalla Direzione nazionale antimafia nonché sulle dinamiche e strategie della criminalità organizzata di tipo mafioso nel periodo $1^{\circ}$ luglio $2005-30$ giugno 2006. Roma: Direzione Nazionale Antimafia, 2006.

. Relazione annuale sulle attività svolte dal Procuratore nazionale antimafia e dalla Direzione nazionale antimafia nonché sulle dinamiche e strategie della criminalità organizzata di tipo mafioso nel periodo $1^{\circ}$ luglio 2007 - 30 giugno 2008. Roma: Direzione Nazionale Antimafia, 2008.

- Relazione annuale sulle attività svolte dal Procuratore nazionale antimafia e dalla Direzione nazionale antimafia nonché sulle dinamiche e strategie della criminalità organizzata di tipo mafioso nel periodo $1^{\circ}$ luglio $2009-30$ giugno 2010. Roma: Direzione Nazionale Antimafia, Dicembre 2010.

- Relazione annuale sulle attività svolte dal Procuratore nazionale antimafia e dalla Direzione nazionale antimafia nonché sulle dinamiche e strategie della criminalità organizzata di tipo mafioso nel periodo $1^{\circ}$ luglio 2010 - 30 giugno 2011. Roma: Direzione Nazionale Antimafia, 2011. 
- Relazione Annuale Sulle Attività Svolte Dal Procuratore Nazionale Antimafia

E Dalla Direzione Nazionale Antimafia Nonché Sulle Dinamiche E Strategie

Della Criminalità Organizzata Di Tipo Mafioso Nel Periodo $1^{\circ}$ Luglio 2011 - 30

Giugno 2012. Roma: Direzione Nazionale Antimafia, 2012.

Dorn, Nicholas, Stijn Van Daele, and Tom Vander Beken. "Reducing Vulnerabilities to Crime of the European Waste Management Industry: The Research Base and the Prospects for Policy." European Journal of Crime, Criminal Law and Criminal Justice 15, no. 1 (2007): 23-36.

Elliott, Lorraine. "Fighting Transnational Environmental Crime.” Journal of International Affairs 66, no. 1 (2012): 87-104.

ETC/RWM. Transboundary Shipments of Waste in the EU. Developments 1995-2005 and Possible Drivers. Technical Report. Copenhagen: European Topic Centre on Resource and Waste Management, 2008.

Eurispes. 'Ndrangheta holding: Dossier 2008. Roma: Istituto di studi politici, economici e sociali, 2008.

http://www.eurispes.it/index.php?option=com_content $\&$ view $=$ article $\&$ id=365:n drangheta-holding-dossier-2008\&catid=56: criminalitaesicurezza\&Itemid=323.

_. L'Italia in gioco: percorsi e numeri della fortuna. Roma: Istituto di studi politici, economici e sociali, 2009.

European Commission. Report on EU Customs Enforcement of Intellectual Property Rights 2010. Brussels: European Commission, 2010.

Europol. OCTA 2011. EU Organised Crime Threat Assessment. The Hague: European Police Office, 2011. https://www.europol.europa.eu/sites/default/files/publications/octa_2011_1.pdf. Feinstein, Dianne, Charles Schumer, and Sheldon Whitehouse. Halting U.S. Firearms Trafficking to Mexico. Washington: United States Senate Caucus on International Narcotics Control, 2011. http://www.feinstein.senate.gov/public/index.cfm?Fuseaction=Files.View\&File Store_id=beaff893-63c1-4941-9903-67a0dc739b9d.

Ferentzy, Peter, and Nigel Turner. "Gambling and Organized Crime - a Review of the Literature.” Journal of Gambling Issues 23 (2009): 111-155.

Fröhlich, Tanja. Organised Environmental Crime in the EU Member States. Final Report. Kassel: Betreuungsgesellschaft für Umweltfragen, 2003. http://ec.europa.eu/environment/legal/crime/pdf/organised_member_states.pdf. 
Frontier Economics. Estimating the Global Economic and Social Impacts of

Counterfeiting and Piracy. London: Business Action to Stop Counterfeiting and Piracy, 2011.

http://www.iccwbo.org/uploadedFiles/BASCAP/Pages/Global\%20Impacts\%20\%20Final.pdf.

GAO. Firearms Trafficking. U.S. Efforts to Combat Arms Trafficking to Mexico Face Planning and Coordination Challenges. Washington: Government Accountability Office, 2009. http://www.gao.gov/new.items/d09709.pdf.

Gazel, Ricardo C., Dan S. Rickman, and William N. Thompson. "Casino Gambling and Crime: A Panel Study of Wisconsin Counties.” Managerial and Decision Economics 22, no. 1/3 (2001): 65-75.

Gruppo Abele-Nomos, Legambiente, and GEPEC-EC. The illegal trafficking in hazardous waste in Italy and Spain. Final Report. Rome: Gruppo Abele-Nomos, Legambiente e Grup d'Estudi i Protecciò dels Ecosistemes del CampEcologistes de Catalunya, October 2003.

Guardia di Finanza. Guardia Di Finanza's Fight against Counterfeiting and Products Piracy. Brussels: Guardia di Finanza, 2003.

Hayman, Gavin, and Duncan Brack. International Environmental Crime. The Nature and Control of Environmental Black Markets. Workshop report. London: Royal Institute of International Affairs, 2002.

ISPAC. Trafficking: Networks and Logistics of Transnational Crime and International Terrorism. International Scientific and Professional Advisory Council of the United Crime Prevention and Criminal Justice Programme, 2002. http://ispac.cnpds.org/publications-16-trafficking-networks-and-logistics-oftransnational-crime-and-international-16.html.

ISPRA. Rapporto Rifiuti 2008. Roma: Istituto Superiore per la Protezione e la Ricerca Ambientale, 2009. http://www.reteambiente.it/normativa/11723/.

—. Rapporto Rifiuti Speciali. Edizione 2010. Roma: Istituto Superiore per la Protezione e la Ricerca Ambientale, 2010. http://www.gruppohera.it/binary/hr_ambiente/angolo_scientifico/rap_125_2010 Rapporto_rifiuti_speciali2010.1310544396.pdf.

—. Rapporto Rifiuti Speciali. Edizione 2011. Roma: Istituto Superiore per la Protezione e la Ricerca Ambientale, 2012. 
http://www.isprambiente.gov.it/site/_contentfiles/00011100/11107_rifiuti_spec_ 2011_rap_155_2011_.pdf.

- Rapporto Rifiuti Speciali. Edizione 2012. Roma: Istituto Superiore per la Protezione e la Ricerca Ambientale, 2013.

—. Rapporto Rifiuti Urbani 2012. Roma: Istituto Superiore per la Protezione e la Ricerca Ambientale, 2012.

Istituto Piepoli. La Contraffazione in Italia. Milano: Confcommercio, 2007. http://www.largoconsumo.info/052008/DOCConfcommercioLacontraffazionein Italia05-08.pdf.

Kim, Geum-Soo, Young-Jae Chang, and David Kelleher. "Unit Pricing of Municipal Solid Waste and Illegal Dumping: An Empirical Analysis of Korean Experience.” Environmental Economics and Policy Studies 9, no. 3 (2008): 167-176.

Kleck, Gary. "BATF Gun Trace Data and the Role of Organized Gun Trafficking in Supplying Guns to Criminals.” Saint Louis University Public Law Review 18 (1999): 23-40.

Koper, Christopher S. Crime Gun Risk Factors: Buyer, Seller, Firearm and Transaction Characteristics Associated with Gun Trafficking and Criminal Gun. Philadelphia: Jerry Lee Center of Criminology - University of Pennsylvania, 2007. http://www.ncjrs.gov/pdffiles1/nij/grants/221074.pdf.

KPMG. La Contraffazione in Italia. Geneva: American Chamber of Commerce in Italy, 2003.

Legambiente. Ecomafia 2012. Le storie e i numeri della criminalità ambientale. Milano: Edizioni Ambiente, 2012.

—_. "Rifiuti Spa". I traffici illegali di rifiuti in Italia. Le storie, i numeri, le rotte e le responsabilità. Roma: Legambiente, Gennaio 2003. http://www.legambienteverona.it/doc/rifiuti/2003-Rifiuti-spa.pdf.

Legambiente, and Carabinieri Tutela Ambiente. "Rifiuti Spa". Radiografia dei traffici illeciti. Roma: Osservatorio nazionale ambiente e legalità di Legambiente e Comando Carabinieri per la tutela dell'ambiente, 2005. http://risorse.legambiente.it/docs/rifiuti_spa_2005.0000002011.pdf.

Libera. Azzardopoli, il paese del gioco d'azzardo, dove quando il gioco si fa duro, le mafie iniziano a giocare. Roma: Libera associazioni, nomi e numeri contro le mafie, 2012. 
LibPie. Il gioco d'azzardo tra legale ed illegale: un focus sul Piemonte. Roma:

Osservatorio Regionale di Libera Piemonte, 2012.

Liddick, Don. "The Enterprise 'model' of Organized Crime: Assessing Theoretical Propositions.” Justice Quarterly 16, no. 2 (1999): 403-430.

. "The Traffic in Garbage and Hazardous Wastes: An Overview." Trends in Organized Crime 13, no. 2-3 (2010): 134-146.

Liddick, Donald R. Crimes Against Nature: Illegal Industries and the Global Environment. Santa Barbara, CA: ABC-CLIO, 2011.

Marsh, Nicholas. "Two Sides of the Same Coin? The Legal and Illegal Trade in Small Arms." The Brown Journal of World Affairs 9 (2002): 217-228.

Massari, Monica, and Paola Monzini. "Dirty Businesses in Italy: A Case-Study of Illegal Trafficking in Hazardous Waste.” Global Crime 6, no. 3-4 (2004): 285304.

Menduini, Marco, and Ferruccio Sansa. "Videopoker, 100 miliardi non riscossi dai Monopoli e finiti alla mafia." Il Secolo XIX, 2007. http://www.ilsecoloxix.it/p/italia_e_mondo/2007/05/31/AKDo9t0videopoker_miliardi_riscossi.shtml\#axzz1uXUue08C.

OECD. Magnitude of Conuterfeiting and Piracy of Tangible Products: An Update, 2009. http://www.oecd.org/dataoecd/57/27/44088872.pdf.

- The Economic Impact of Counterfeiting and Piracy. Paris: Organisation for Economic Co-operation and Development, 2008.

Rainelli, Sara. "Le Armi Leggere Nel Mondo.” Sistema Informativo a Schede 1 (2012): $1-23$.

Reuter, Peter. "The (continued) Vitality of Mythical Numbers.” The Public Interest 75 (1984): 135-147.

Reuter, Peter, and Jonathan Rubinstein. Illegal Gambling in New York: A Case Study in the Operation, Structure, and Regulation of an Illegal Market. Washington D.C.: U.S. Department of Justice, National Institute of Justice, 1982.

Ruggiero, Vincenzo. "Criminals and Service Providers: Cross-National Dirty Economies." Crime, Law and Social Change 28, no. 1 (1997): 27-38.

Sagramoso, Domitilla. The Proliferation of Illegal Small Arms and Light Weapons in and around the European Union: Instability, Organised Crime and Terrorist Groups. London: Centre for Defense Studies - Kings College, University of London, 2001. http://www.isn.ethz.ch/isn/Digital- 
Library/Publications/Detail/?ots591=0c54e3b3-1e9c-be1e-2c24a6a8c7060233\&lng=en\&id=10251.

Savona, Ernesto Ugo. “Italian Mafias’ Asymmetries.” In Traditional Organized Crime in the Modern World: Responses to Socioeconomic Change, edited by Dina Siegel and Hank van de Bunt, 3-25. New York: Springer, 2012.

Sigman, Hilary. "Midnight Dumping: Public Policies and Illegal Disposal of Used Oil." The RAND Journal of Economics 29, no. 1 (1998): 157-178.

Singer, Max. "The Vitality of Mythical Numbers." The Public Interest 23 (1971): 3-9.

Small Arms Survey. Small Arms Survey 2002: Counting the Human Cost. Geneva: Graduate Institute of International Studies, 2002. http://www.smallarmssurvey.org/publications/by-type/yearbook/small-armssurvey-2002.html.

SOS Impresa. Le mani della criminalità sulle imprese. Roma: Confesercenti, 2011. Le mani della criminalità sulle imprese. Roma: Confesercenti, 2012.

Spapens, Toine. "Trafficking in Illicit Firearms for Criminal Purposes within the European Union.” European Journal of Crime, Criminal Law and Criminal Justice 15, no. 3-4 (2007): 359-381.

Stohl, Rachel J. "Fighting the Illicit Trafficking of Small Arms." SAIS Review 25, no. 1 (2005): 59-68.

Strumpf, Koleman. “Illegal Sports Bookmakers.” Department of Economics University of North Carolina and Chapel Hill, 2003. http://www.unc.edu/ cigar/papers/Bookie4b.pdf.

The Council of the European Union. Council Directive 1999/31/EC on the Landfill of Waste, 1999.

Tompson, Lisa, and Spencer Chainey. "Profiling Illegal Waste Activity: Using Crime Scripts as a Data Collection and Analytical Strategy." European Journal on Criminal Policy and Research 17, no. 3 (2011): 179-201.

Transcrime. Anti-Brand Counterfeiting in the EU: Report on Best Practices. Milan: Transcrime, 2010. http://www.gacg.org/Content/Upload/Documents/Transcrime_Report\%20Best\% 20Practices_Project\%20FAKES.pdf.

Anti-Brand Counterfeiting in the EU: Report on International and National Existing Standards. Milan: Transcrime, 2010. 
http://www.gacg.org/Content/Upload/Documents/Transcrime_Report\%20Existi ng\%20Standards_Project\%20FAKES.pdf.

. Progetto PON Sicurezza 2007-2013: Gli investimenti delle mafie. Rapporto Linea 1. Milano: Ministero dell'Interno, 2013. www.investimentioc.it.

UNICRI. Contraffazione: Una Diffusione Globale, Una Minaccia Globale. Torino:

United Nations Interregional Crime and Justice Research Institute, 2007. http://counterfeiting.unicri.it/report2008.php.

Union des Fabricants. Counterfeiting and Organized Crime Report. Paris: Union des Fabricants, 2003.

UNODC. The Globalization of Crime: A Transnational Organized Crime Threat Assessment. Vienna: United Nations Office on Drugs and Crime, 2010. http://www.unodc.org/documents/data-andanalysis/tocta/TOCTA_Report_2010_low_res.pdf.

—. Transnational Trafficking and the Rule of Law in West Africa. A Threat Assessment. Vienna: United Nation Office on Drugs and Crime, 2009. http://www.unodc.org/documents/data-andanalysis/Studies/West_Africa_Report_2009.pdf.

Vander Beken, Tom. The European Waste Industry and Crime Vulnerabilities. Antwerp-Apeldoorn: Maklu Publishers, 2007.

Vander Beken, Tom, and Annelies Balcaen. "Crime Opportunities Provided by Legislation in Market Sectors: Mobile Phones, Waste Disposal, Banking, Pharmaceuticals.” European Journal on Criminal Policy and Research 12, no. 34 (2006): 299-323.

WCO. Customs and IPR Report 2010. Brussels: World Customs Organization, 2011. http://www.wcoomd.org/files/1.\%20Public\%20files/PDFandDocuments/Enforce ment/WCO_Customs_IPR_2010_public_en.pdf.

Wielenga, Kees. Waste Without Frontiers. Global Trends in the Generation of Transboundary Movements of Hazardous Wastes and Other Wastes. Geneva: The Secretariat of the Basel Convention, 2010. 


\section{Appendix}

Table 4. Minimum and maximum estimates of the revenues of the markets for illegal firearms (year 2010), counterfeit goods (year 2008) and special waste (years 2007-2010) (mn €) per type of estimate or product/service.

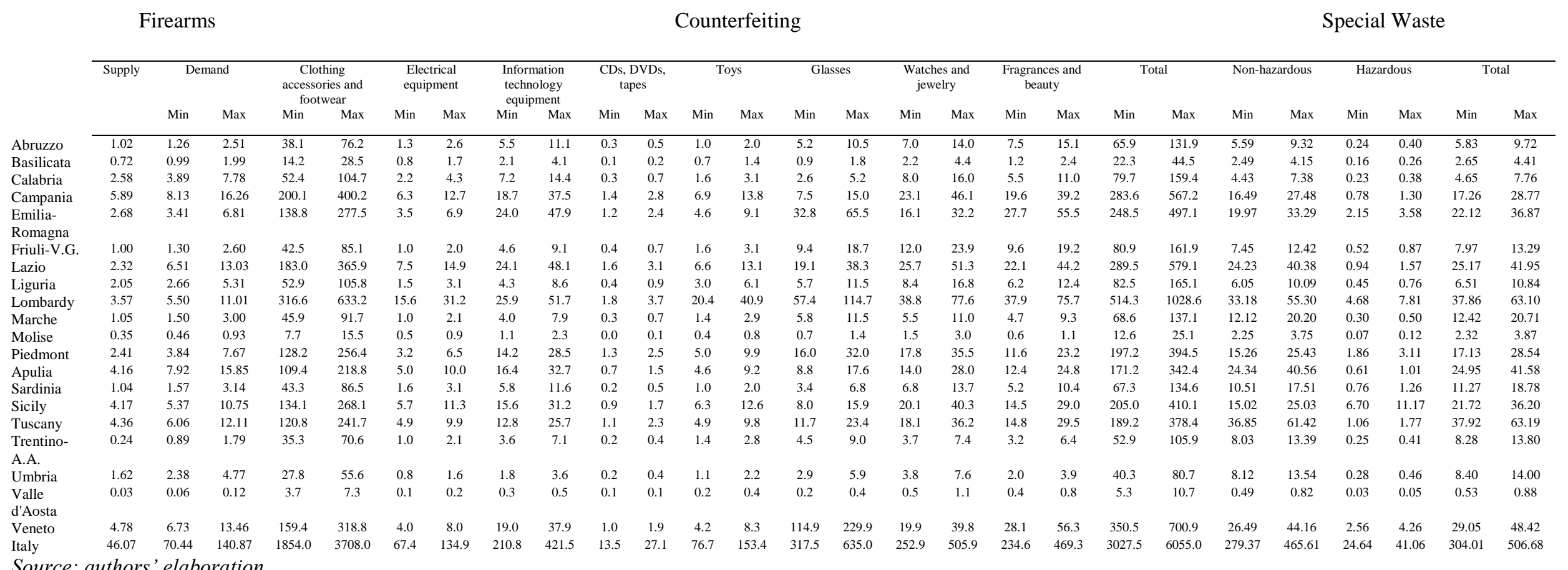

Source: authors' elaboration 


\section{Notes}

${ }^{1}$ Preliminary versions of the methodologies presented in this article were developed in a research project awarded by the Italian Ministry of Interior to Transcrime (Joint Research Centre on Transnational Crime of Università Cattolica del Sacro Cuore of Milan and Università di Trento). See Transcrime, Progetto PON Sicurezza 2007-2013: Gli investimenti delle mafie. Rapporto Linea 1.

${ }^{2}$ Marsh, "Two Sides of the Same Coin? The Legal and Illegal Trade in Small Arms"; ISPAC, Trafficking: Networks and Logistics of Transnational Crime and International Terrorism. Considered here is only the black market. The distinction depends on four factors: the status of the buyer, the status of the seller, the status of the weapon, and the status of the transaction. See Ruggiero, "Criminals and Service Providers," 32-33; Cukier, The Illicit Trade in Small Arms: Addressing the Problem of Diversion, 1.

3 'Diversion' is the transfer of arms from the legal market to the illegal one. Stohl, "Fighting the Illicit Trafficking of Small Arms," 61.

${ }^{4}$ Spapens, "Trafficking in Illicit Firearms for Criminal Purposes Within the European Union."

${ }^{5}$ Cukier, The Illicit Trade in Small Arms: Addressing the Problem of Diversion.

6 'Straw purchasers' are individuals eligible to buy firearms. They buy weapons on behalf of third parties (usually representatives of criminals or intermediaries) in return for money. See Kleck, "BATF Gun Trace Data and the Role of Organized Gun Trafficking in Supplying Guns to Criminals"; Koper, Crime Gun Risk Factors: Buyer, Seller, Firearm and Transaction Characteristics Associated with Gun Trafficking and Criminal Gun; GAO, Firearms Trafficking. U.S. Efforts to Combat Arms Trafficking to Mexico Face Planning and Coordination Challenges; UNODC, The Globalization of Crime: A Transnational Organized Crime Threat Assessment; Feinstein, Schumer, and Whitehouse, Halting U.S. Firearms Trafficking to Mexico.

${ }^{7}$ Ruggiero, "Criminals and Service Providers," 33.

${ }^{8}$ Rainelli, "Le Armi Leggere Nel Mondo," 9.

${ }^{9}$ For instance, the UN Office on Drugs and Crime estimates that the global value of the illegal firearms market is from $\$ 170$ million to $\$ 320$ million annually (UNODC 2010). As regards the illegal traffic from the United States to Mexico, the UNODC evaluates it at around 20,000 pieces a year for a value of \$20 million (UNODC 2010). There are around 1.6 million weapons in Central America, of which 500,000 are legally registered (UNODC 
2007). This figure is substantially confirmed by the Small Arms Survey report of 2002, according to which there are about 800,000 unregistered weapons in the region. See Small Arms Survey, Small Arms Survey 2002: Counting the Human Cost. In Africa, it is estimated that illegal weapons amount to about 2 million, for a value in the destination countries of $\$ 167$ million (UNODC 2009). The firearms trade from Eastern European countries to the rest of the world has an annual volume of about 40,000 Kalashnikovs, for a value of US\$33 million (UNODC 2010).

${ }^{10}$ Marsh, "Two Sides of the Same Coin? The Legal and Illegal Trade in Small Arms," 220; Cukier, The Illicit Trade in Small Arms: Addressing the Problem of Diversion, 3; UNODC, The Globalization of Crime: A Transnational Organized Crime Threat Assessment, 129.

${ }^{11}$ Sagramoso, The Proliferation of Illegal Small Arms and Light Weapons in and Around the European Union: Instability, Organised Crime and Terrorist Groups.

${ }^{12}$ Angeli, "Pistole, Kalashnikov, Persino Un Missile Grandi Affari Al Supermarket Dei 'Ferri'." ${ }^{13}$ Ibid.

${ }^{14}$ DIA, Relazione del Ministro dell'Interno al Parlamento sull'attività svolta e sui risultati conseguiti dalla Direzione Investigativa Antimafia: Secondo semestre 2011; DNA, Relazione annuale 2011.

${ }^{15}$ Eurispes, 'Ndrangheta holding: Dossier 2008; SOS Impresa, Le mani della criminalità sulle imprese, 2012.

${ }^{16}$ Eurispes, 'Ndrangheta holding: Dossier 2008.

${ }^{17}$ This estimate is based on data contained in the 2008 report of the Parliamentary Anti-Mafia Commission. SOS Impresa, Le mani della criminalità sulle imprese, 2012.

${ }^{18}$ DNA, Relazione annuale 2011; Relazione annuale 2010; DIA, Relazione del Ministro dell'Interno al Parlamento sull'attività svolta e sui risultati conseguiti dalla Direzione Investigativa Antimafia: Secondo semestre 2011; Relazione del Ministro dell'Interno al Parlamento sull'attività svolta e sui risultati conseguiti dalla Direzione Investigativa Antimafia: Secondo semestre 2010.

${ }^{19}$ The TRIPs Agreement, created by the World Trade Organization (WTO), in a note to article 51 defines the concept of counterfeiting in terms of counterfeit trademark goods, and piracy in those of pirated copyright goods. Numerous studies use this distinction because, at international level, the concepts of counterfeiting and piracy are often considered as connected with the issue of infringement of intellectual property rights. Among them: Transcrime, Anti-Brand Counterfeiting in the EU: Report on International and National 
Existing Standards; OECD, The Economic Impact of Counterfeiting and Piracy; UNICRI, Contraffazione: Una Diffusione Globale, Una Minaccia Globale.

${ }^{20}$ WCO, Customs and IPR Report 2010.

${ }^{21}$ China has acquired a leading role in the production of counterfeits in the past ten years. According to the World Customs Organization, $58 \%$ of seized shipments originate from China, 19\% from Taiwan, followed by India and the United Arab Emirates (Ibid.). These figures are confirmed by the EU, which identifies China as the main country of origin of counterfeited goods. European Commission, Report on EU Customs Enforcement of Intellectual Property Rights 2010.

${ }^{22}$ European Commission, Report on EU Customs Enforcement of Intellectual Property Rights 2010.

${ }^{23}$ Ibid.

${ }^{24}$ UNICRI, Contraffazione: Una Diffusione Globale, Una Minaccia Globale.

${ }^{25}$ Transcrime, Anti-Brand Counterfeiting in the EU: Report on Best Practices; UNODC, The Globalization of Crime: A Transnational Organized Crime Threat Assessment; UNICRI, Contraffazione: Una Diffusione Globale, Una Minaccia Globale.

${ }^{26}$ Frontier Economics, Estimating the Global Economic and Social Impacts of Counterfeiting and Piracy; WCO, Customs and IPR Report 2010; European Commission, Report on EU Customs Enforcement of Intellectual Property Rights 2010; OECD, Magnitude of Conuterfeiting and Piracy of Tangible Products: An Update; OECD, The Economic Impact of Counterfeiting and Piracy.

${ }^{27}$ OECD, The Economic Impact of Counterfeiting and Piracy.

${ }^{28}$ OECD, Magnitude of Conuterfeiting and Piracy of Tangible Products: An Update.

${ }^{29}$ DNA, Relazione annuale 2011.

${ }^{30}$ DNA, Relazione annuale 2010; Union des Fabricants, Counterfeiting and Organized Crime Report.

${ }^{31}$ Europol, OCTA 2011. EU Organised Crime Threat Assessment.

${ }^{32}$ KPMG, La Contraffazione in Italia.

${ }^{33}$ Confesercenti, Contraffazione e criminalità informatica: $i$ danni all'economia e alle imprese.

${ }^{34}$ Istituto Piepoli, La Contraffazione in Italia.

${ }^{35}$ The economic sectors analyzed were: audio-visual equipment and pay TV, music, software and video games, books and fashion field. 
${ }^{36}$ KPMG, La Contraffazione in Italia.

${ }^{37}$ Guardia di Finanza, Guardia Di Finanza's Fight Against Counterfeiting and Products Piracy.

${ }^{38}$ CENSIS, "Comunicati stampa - CENSIS."

${ }^{39}$ CENSIS, L'impatto della contraffazione sul sistema-Paese: dimensioni, caratteristiche e approfondimenti.

${ }^{40}$ Cornish, Gambling: a Review of the Literature and Its Implications for Policy and Research; Gazel, Rickman, and Thompson, "Casino Gambling and Crime"; Ferentzy and Turner, "Gambling and Organized Crime - a Review of the Literature."

${ }^{41}$ Strumpf, "Illegal Sports Bookmakers."

${ }^{42}$ Reuter and Rubinstein, Illegal Gambling in New York: a Case Study in the Operation, Structure, and Regulation of an Illegal Market.

${ }^{43}$ Liddick, "The Enterprise 'model' of Organized Crime."

${ }^{44} \mathrm{CPA}$, Relazione sul fenomeno delle infiltrazioni mafiose nel gioco lecito ed illecito; DNA, Relazione annuale 2011; Libera, Azzardopoli, il paese del gioco d'azzardo, dove quando il gioco si fa duro, le mafie iniziano a giocare.

${ }^{45} \mathrm{CPA}$, Relazione sul fenomeno delle infiltrazioni mafiose nel gioco lecito ed illecito.

${ }^{46}$ DNA, Relazione annuale 2000; DNA, Relazione annuale 2011.

${ }^{47}$ DNA, Relazione annuale 2011.

${ }^{48}$ LibPie, Il gioco d'azzardo tra legale ed illegale: un focus sul Piemonte.

${ }^{49}$ Data are periodically published on the AAMS website (http://www.aams.gov.it).

${ }^{50} \mathrm{New}$ slot machines (regulated by paragraph 6a of Article 110 of the public security law (TULPS)) are controlled by an electronic card or smart card. In these devices, the cost of the game cannot be more than $€ 1$ and the payout may not exceed $€ 100$. Moreover, in a cycle of no more than 140,000 games, winnings (i.e. the payout) must not be less than $75 \%$ of the stakes.

Video lottery terminals or VLT (regulated by paragraph $6 \mathrm{~b}$ of the above mentioned law) are directly connected to the server of the licensed dealer from which games are downloaded. In practice, the game software is not in the machine but is installed on the computer network operated by the licensed dealer. The cost of a game can be up to $€ 10$ and winnings up to $€ 5,000$, or $€ 500,000$ in the case of a jackpot. The payout must not be less than $85 \%$ of the stakes. VLTs, introduced by the 2006 budget law, were in fact brought 
into service in late 2010. They cannot be installed in bars, but only in premises specifically dedicated to gambling. DNA, Relazione annuale 2011.

${ }^{51}$ DNA, Relazione annuale 2006.

${ }^{52}$ DNA, Relazione annuale 2000; DNA, Relazione annuale 2008; DNA, Relazione annuale 2011.

${ }^{53}$ DNA, Relazione annuale 2011, 297.

${ }^{54}$ DNA, Relazione annuale 2006.

${ }^{55}$ Commission of inquiry to verify the regularity and transparency of procedures for granting authorizations regarding entertainment equipment and devices, to analyze the functioning of processes, also technological, ensuring that games take place lawfully.

${ }^{56} \mathrm{CPA}$, Relazione sul fenomeno delle infiltrazioni mafiose nel gioco lecito ed illecito.

${ }^{57}$ Menduini and Sansa, "Videopoker, 100 miliardi non riscossi dai Monopoli e finiti alla mafia."

${ }^{58}$ LibPie, Il gioco d'azzardo tra legale ed illegale: un focus sul Piemonte.

${ }^{59} 12,554$ seizures in 2009 vs. 1,806 in 2011 (data from AAMS).

${ }^{60}$ LibPie, Il gioco d'azzardo tra legale ed illegale: un focus sul Piemonte.

${ }^{61}$ Eurispes, L'Italia in gioco: percorsi e numeri della fortuna.

${ }^{62}$ SOS Impresa, Le mani della criminalità sulle imprese, 2011.

${ }^{63}$ Tompson and Chainey, "Profiling Illegal Waste Activity: Using Crime Scripts as a Data Collection and Analytical Strategy," 180.

${ }^{64}$ Tompson and Chainey, "Profiling Illegal Waste Activity: Using Crime Scripts as a Data Collection and Analytical Strategy"; Fröhlich, Organised Environmental Crime in the EU Member States.

${ }^{65}$ Liddick, "The Traffic in Garbage and Hazardous Wastes: An Overview"; Tompson and Chainey, "Profiling Illegal Waste Activity: Using Crime Scripts as a Data Collection and Analytical Strategy."

${ }^{66}$ Massari and Monzini, "Dirty Businesses in Italy: a Case-study of Illegal Trafficking in Hazardous Waste"; Vander Beken and Balcaen, "Crime Opportunities Provided by Legislation in Market Sectors: Mobile Phones, Waste Disposal, Banking, Pharmaceuticals"; Vander Beken, The European Waste Industry and Crime Vulnerabilities; Dorn, Van Daele, and Vander Beken, "Reducing Vulnerabilities to Crime of the European Waste Management Industry: The Research Base and the Prospects for Policy"; Liddick, "The Traffic in Garbage and Hazardous Wastes: An Overview"; Liddick, Crimes Against Nature; Tompson and Chainey, "Profiling Illegal Waste Activity: Using Crime Scripts as a Data Collection and Analytical Strategy." 
${ }^{67}$ See, for example, Hayman and Brack, International Environmental Crime. The Nature and Control of Environmental Black Markets.

${ }^{68}$ See, among others, Sigman, "Midnight Dumping: Public Policies and Illegal Disposal of Used Oil"; Kim, Chang, and Kelleher, "Unit Pricing of Municipal Solid Waste and Illegal Dumping.”

${ }^{69}$ Gruppo Abele-Nomos, Legambiente, and GEPEC-EC, The illegal trafficking in hazardous waste in Italy and Spain, 24.

${ }^{70}$ Elliott, "Fighting Transnational Environmental Crime," 91.

${ }^{71}$ Hayman and Brack, International Environmental Crime. The Nature and Control of Environmental Black Markets, 13.

${ }^{72}$ Legambiente, "Rifiuti Spa". I traffici illegali di rifiuti in Italia. Le storie, i numeri, le rotte e le responsabilità, 12; Gruppo Abele-Nomos, Legambiente, and GEPEC-EC, The illegal trafficking in hazardous waste in Italy and Spain, 22; Massari and Monzini, "Dirty Businesses in Italy: a Case-study of Illegal Trafficking in Hazardous Waste," 292.

${ }^{73}$ Dorn, Van Daele, and Vander Beken, "Reducing Vulnerabilities to Crime of the European Waste Management Industry: The Research Base and the Prospects for Policy," 27-28.

${ }^{74}$ Europol, OCTA 2011. EU Organised Crime Threat Assessment, 40; UNODC, Transnational Trafficking and the Rule of Law in West Africa. A Threat Assessment, 58.

${ }^{75}$ Europol, OCTA 2011. EU Organised Crime Threat Assessment, 40.

${ }^{76}$ Albrecht, "The Extent of Organized Environmental Crime. A European Perspective," 100; UNODC, Transnational Trafficking and the Rule of Law in West Africa. A Threat Assessment, 58.

${ }^{77}$ Wielenga, Waste Without Frontiers. Global Trends in the Generation of Transboundary Movements of Hazardous Wastes and Other Wastes.

${ }^{78}$ For example, EU Member States must report cases of illegal shipments of waste to the EU Commission every year. However, not all the States report regularly, and many of the reported cases lack information on the amount of waste illegally shipped. See ETC/RWM, Transboundary Shipments of Waste in the EU. Developments 1995-2005 and Possible Drivers.

${ }^{79}$ Of particular importance is that in 2010 competence to investigate the offense of "Organized activities for the illegal trafficking of waste" was moved from the Prosecutor's offices to the Anti-mafia Directorates.

${ }^{80}$ DNA, Relazione Annuale Sulle Attività Svolte Dal Procuratore Nazionale Antimafia e Dalla Direzione Nazionale Antimafia Nonché Sulle Dinamiche e Strategie Della Criminalità Organizzata Di Tipo Mafioso Nel Periodo $1^{\circ}$ Luglio 2011 - 30 Giugno 2012, 333. 
${ }^{81}$ Albrecht, "The Extent of Organized Environmental Crime. A European Perspective," 97.

${ }^{82}$ Massari and Monzini, "Dirty Businesses in Italy: a Case-study of Illegal Trafficking in Hazardous Waste," 299; Gruppo Abele-Nomos, Legambiente, and GEPEC-EC, The illegal trafficking in hazardous waste in Italy and Spain, 24.

${ }^{83}$ DNA, Relazione annuale 2011; Relazione Annuale Sulle Attività Svolte Dal Procuratore Nazionale Antimafia e Dalla Direzione Nazionale Antimafia Nonché Sulle Dinamiche e Strategie Della Criminalità Organizzata Di Tipo Mafioso Nel Periodo $1^{\circ}$ Luglio 2011 - 30 Giugno 2012.

${ }^{84}$ Data from the Italian Antimafia District Directorates (DDAs) on criminal proceedings for the offence of "organized activities for the illegal trafficking of waste" (art. 260 Legislative Decree 152/2006) and referring to the period January 2010-June 2012 show that the phenomenon is widespread also in areas without a traditional mafia presence. The districts of Bologna, Brescia, Florence and Venice recorded a number of proceedings similar to and sometimes higher than Southern districts such as Naples, Palermo and Reggio Calabria (DNA, Relazione Annuale Sulle Attività Svolte Dal Procuratore Nazionale Antimafia e Dalla Direzione Nazionale Antimafia Nonché Sulle Dinamiche e Strategie Della Criminalità Organizzata Di Tipo Mafioso Nel Periodo $1^{\circ}$ Luglio 2011 - 30 Giugno 2012, 325-326.).

${ }^{85}$ Albrecht, "The Extent of Organized Environmental Crime. A European Perspective," 97.

${ }^{86}$ Legambiente, Ecomafia 2012. Le storie e i numeri della criminalità ambientale, 68.

${ }^{87}$ The methodology used was based on calculation of the so-called rifiuti scomparsi (missing waste), that is, the difference between waste produced and waste managed in approved facilities. This missing amount was attributed to the illegal market. Legambiente estimated the revenues of the illegal special waste market on the basis of these data, and prices prevailing in the legal market.

${ }^{88}$ Number of firearms seized/confiscated by the province of seizure/confiscation. Data regarding 2009, 2010 and 2011 have been used by calculating the average value. The average number of firearms seized/confiscated in the period 2009-2011 has been used because, in many cases, values for each single year were significantly different from those for the other years. It was consequenty decided to calculate the average value so as to make it more stable over time. With regard to data on seizures and confiscations, to be noted is that the reasons for the seizure/confiscation of a weapon cannot be attributed only to illicit trafficking or related activities but to all provisions contained in the Italian law on firearms. Therefore, figures should be considered as rounded up. Data have been provided by the Italian police force database SDI (Sistema D'Indagine). 
${ }^{89}$ Transcrime, Progetto PON Sicurezza 2007-2013: Gli investimenti delle mafie. Rapporto

Linea 1, 310-314 and 342.

${ }^{90}$ These estimates are based on the findings in the literature, namely the calculation that the illegal traffic amounts to between $10 \%$ and $20 \%$ of the legal one. Data on imports and exports refer to the total monetary value of imported/exported firearms from/to Italy (years 2009-2011). The average value of exports was $€ 482,220,636$; while that of imports was $€ 106,786,382$. These data have been downloaded from the UN Commodity Trade Statistics Database. This variable includes data on "Arms and ammunition, parts and accessories thereof" (code HS 1992, 93 of the Commodity Trade database). In particular, the following categories have been considered: Air gun pellets, parts of shotgun cartridges; Arms not elsewhere specified or "nes" (spring/air/gas guns, truncheons, etc.); Cartridges nes, parts thereof; Cartridges, shotguns; Munitions of war, ammunition/projectiles and parts; Muzzle-loading firearms; Parts and accessories nes of weapons, nes; Parts and accessories of revolvers or pistols; Parts and accessories of shotguns or rifles, nes; Revolvers and pistols; Rifles, sporting, hunting or target-shooting, nes; Shotgun barrels; Shotguns, shotgun-rifles for sport, hunting or target; Signal pistols, etc., humane killers, etc. The turnover of the Italian companies refers to those companies manufacturing firearms and ammunition belonging to the National Associations of Sportive and Civil Weapons and Ammunition Manufacturers (ANPAM). Estimates have been calculated only for 2010 because data were available only for that year. The total turnover amounted to $€ 486,338,624$ while the turnover generated by the national market was equal to $€ 115,347,891$. Data from ANPAM include, besides firearms, also parts of weapons, cartridges and ammunitions.

${ }^{91}$ It was assumed that the the regional market is larger where there are more inhabitants.

${ }^{92}$ It was also assumed that revenues are higher where there are more firearms seized/confiscated. For this purpose, data on seizures and confiscations of firearms between 2009 and 2011 have been used. As already mentioned, owing to the great variability of these data, it was decided to calculate the regional average. Then calculated from the average number of firearms seized and confiscated was the rate per 100,000 inhabitants (based on the average population for the same years) at the regional and national level.

${ }^{93}$ This formula was applied for both illegal demand at $10 \%(\min )$ and $20 \%$ (max) of the legal one.

${ }^{94}$ At first, data on seized goods by region and product category were included in the analysis for the years 2008-2011. The results seemed to be insufficiently representative of the 
phenomenon of counterfeiting in Italy and for this reason other variables were taken into account.

${ }^{95}$ The ATECO classification of the economic sectors is the classification used by the Italian Institute of Statistic (ISTAT) to classify economic activities. Data on turnovers were collected from the I.STAT and AIDA datasets, and the data on employees from I.STAT.

${ }^{96}$ Turnovers were calculated for all sectors using the I.STAT database, except for the category "Watches". For the latter, I.STAT did not provide a sufficient level of disaggregation, so that the AIDA database was used. Unfortunately, AIDA provides only the turnover of the last available year. To compensate for this characteristic of AIDA, it was decided to include the enterprises' turnover from 2004 to 2011. The purpose was to avoid the loss of information of companies that had not provided more updated data.

${ }^{97}$ Data periodically provided by AAMS at http://www.aams.gov.it/?id=5320.

${ }^{98}$ DNA, Relazione annuale 2011.

${ }^{99}$ Data from AAMS website (www.amms.gov.it)

${ }^{100}$ Data provided by AAMS.

${ }^{101}$ The infringement rate for Trentino-Alto Adige was 0.0, a figure that would have invalidated the following operations. For this reason, Trentino-Alto Adige was assigned the value of 0.17 , i.e. the lowest rate among other regions (Liguria).

${ }^{102}$ Information based on regulations in force and interviews with AAMS staff.

${ }^{103}$ Special waste is the waste generated by production activities. Conversely, municipal waste is the "waste from households, as well as other waste which, because of its nature or composition, is similar to waste from household (The Council of the European Union, Council Directive 1999/31/EC on the Landfill of Waste.).

${ }^{104}$ In some Italian regions the inefficiencies of the public administration in managing municipal waste have been exploited by the mafias, which have entered the waste market. This is particularly the case of the Camorra in Campania. There, the Neapolitan mafia has specialized in criminal activities related to the waste disposal cycle (Savona, "Italian Mafias' Asymmetries,” 10.).

${ }^{105}$ Based on ISPRA data (see ISPRA, Rapporto Rifiuti Urbani 2012; Rapporto Rifiuti Speciali. Edizione 2012.)

${ }^{106}$ Massari and Monzini, "Dirty Businesses in Italy: a Case-study of Illegal Trafficking in Hazardous Waste," 297; Fröhlich, Organised Environmental Crime in the EU Member States, 22. 
${ }^{107}$ ISPRA also provides data on the production, separate collection and management of municipal waste. However, these data did not have the level of detail required for the analysis.

${ }^{108}$ This calculation was necessary because the stored waste may remain in the storage facilities for a time and be disposed of/recovered at a later date; or it may be disposed of/recovered in the same year. The inclusion of the stored waste in legal management would have led to overestimation of the amount of waste managed in a year, while its exclusion would have resulted in an underestimation (ISPRA, Rapporto Rifiuti Speciali. Edizione 2011, 2012, 63-64. Data were derived from ISPRA reports on special waste (Rapporto Rifiuti 2008; Rapporto Rifiuti Speciali. Edizione 2010; Rapporto Rifiuti Speciali. Edizione 2011, 2012; Rapporto Rifiuti Speciali. Edizione 2012.) and referred to the years 2007, 2008, 2009 and 2010. Within the reports the operations of final management are identified by the codes $R I$ to $R 11$ (for recovery) and $D 1$ to $D 12$ and $D 14$ (for disposal). Instead, storage operations are identified by the codes $D 13, D 15, R 12$ and $R 13$.

${ }^{109}$ This redistribution was necessary since, in some Italian regions, the amount of waste managed was larger than the waste produced. Data on the legal production were derived from the same ISPRA reports as above.

${ }^{110}$ Northern Italy comprises the regions of: Piedmont, Valle d'Aosta, Lombardy, Trentino-Alto Adige, Veneto, Friuli-Venezia Giulia, Liguria and Emilia-Romagna. Central Italy includes Tuscany, Umbria, Marche and Lazio. Southern Italy includes Abruzzo, Molise, Campania, Apulia, Basilicata, Calabria, Sicily and Sardinia.

${ }^{111}$ This was due to the fact that the amount of hazardous waste managed in Southern Italy was larger than the waste produced. Thus, considering the macro-area would have led to a negative value of the illegal market in Southern regions.

${ }^{112}$ The average price differed according to the type of waste (hazardous/non-hazardous). Data were obtained by contacting a waste disposal company.

${ }^{113}$ For instance, the incidence of seizures/confiscations in the total amount of illegal firearms or the average price for illegal firearms, the commodity macro-categories chosen for the counterfeiting market, or the price of legal management services used for the illegal waste market. In the latter case the price was obtained from a waste company operating in Northern Italy and it was applied to the entire country. However, some differences among regions or geographical areas may exist.

${ }^{114}$ Legambiente and Carabinieri Tutela Ambiente, "Rifiuti Spa”. Radiografia dei traffici illeciti, 18. 
${ }^{115}$ Singer, "The Vitality of Mythical Numbers"; Reuter, "The (continued) Vitality of Mythical Numbers." 